\title{
Cytogenetics, Ploidy, and Genome Sizes of Camellia and Related Genera
}

\author{
William G. Hembree ${ }^{1}$ and Thomas G. Ranney ${ }^{2,5}$ \\ Mountain Crop Improvement Laboratory, Department of Horticultural \\ Science, Mountain Horticultural Crops Research and Extension Center, \\ North Carolina State University, 455 Research Drive, Mills River, NC \\ 28759-3423 \\ Brian E. Jackson ${ }^{3}$ \\ Department of Horticultural Science, North Carolina State University, \\ Campus Box 7609, Raleigh, NC, 27695-7609
}

\section{Mark Weathington ${ }^{4}$ \\ JC Raulston Arboretum, North Carolina State University, Campus Box 7522, Raleigh, NC 27695-7522}

Additional index words. cytology, DNA content, flow cytometry, chromosomes, plant breeding, polyploidy, Hartia, Polyspora, Pyrenaria, Stewartia, taxonomy, Theaceae, Tutcheria

Abstract. Camellia L., the most speciose member of the diverse tea family Theaceae, has a long and complex horticultural history. Extensive cultivation and hybridization have produced thousands of varieties of Camellia, including commercially important crops such as cultivated tea, oilseed, and iconic flowering shrubs. Cytogenetics of Camellia and related genera is complicated; chromosome number and ploidy can vary widely between species, and interspecific and interploid hybridization occurs. However, specific information regarding cytogenetics of many species, cultivars, and modern hybrids is lacking. The objectives of this study were to compile a consolidated literature review of the cytogenetics of Camellia and related genera and to determine chromosome numbers, ploidy, and genome sizes of specific accessions of selected species, cultivars, and interspecific and interploid hybrids. A review of the existing literature regarding Theaceae cytogenetics is presented as a consolidated reference comprising $\mathbf{3 6 2}$ taxa. Genome sizes were determined with flow cytometry using propidium iodide as a fluorochrome and Pisum sativum 'Ctirad' and Magnolia virginiana 'Jim Wilson' as internal standards. Chromosome numbers of selected taxa were determined using traditional cytology and were used to calibrate genome sizes with ploidy level. Our results confirmed a base chromosome number of $x=15$ for Theeae including Camellia, $x$ $=17$ for Stewartiae, and $\boldsymbol{x}=\mathbf{1 8}$ for Gordoniae. Surveyed camellias ranged from $2 n=\mathbf{2 x}=$ 30 to $2 n=8 x=120$, including diploids, triploids, tetraploids, pentaploids, hexaploids, and octoploids. Previously uncharacterized taxa such as Camellia azalea, $C$. amplexicaulis, $C$. chrysanthoides, C. cordifolia, C. cucphuongensis, $C$. flava, $C$. nanyongensis, and $C$. trichoclada were found to be diploid. Ploidy was also newly determined for Schima argentea, S. khasiana, S. remotiserrata, and S. sinensis (all diploids). Both diploid and triploid Stewartia ovata were found, and a ploidy series was discovered for Polyspora that ranged from diploid to octoploid. Ploidy determinations were used to confirm or challenge the validity of putative interploid hybrids. Monoploid genome sizes varied among subfamily and genera, with $1 \mathrm{C} x$ values ranging from $0.80 \mathrm{pg}$ for Franklinia to a mean of $3.13 \mathrm{pg}$ for Camellia, demonstrating differential rates of genome expansion independent of ploidy. Within Camellia, monoploid genome sizes varied among subgenera, sections, and some species (range, $2.70-3.55 \mathrm{pg}$ ). This study provides a consolidated and expanded knowledgebase of ploidy, genome sizes, hybridity, and reproductive pathways for specific accessions of Camellia and related genera that will enhance opportunities and strategies for future breeding and improvement within Theaceae.

Theaceae (Mirb. ex Ker Gawl.), the tea family, is a small family of trees and shrubs with a disjunct eastern Asian-eastern North American and northern South American distribution (Stevens, 2001 onwards). Camellia L. is the largest and most commercially significant genus of Theaceae, with species found throughout southeastern and eastern Asia (Chang and Bartholomew, 1984; Luna Vega and Contreras-Medina, 2000). Approx- for garden use in China (Xin et al., 2015). Although tea (C. sinensis) arrived in Europe during approximately the middle of the 17 th century, the first living Camellia plant was not reported until nearly one century later, in Lord Petre Thorndon's hothouses in England. Since then, ornamental camellias have become widely cultivated throughout Europe, North America, Australia, and New Zealand (Ackerman, 2007; Darfler, 2014; Trehane, 2007). Their popularity and phenotypic variability have led to tens of thousands of cultivars and hybrids (International Camellia Society, 2015). However, there are many polyploid camellias, and many species and complex hybrids have not been analyzed for ploidy or genome size. Improved knowledge of chromosome numbers and ploidy levels of key species and cultivars would be a valuable resource for further breeding and improvement of Camellia. Analyses of other closely related genera would provide a broader understanding of ploidy within Theaceae and help contextualize evolutionary relationships in this family.

\section{Taxonomy/Systematics}

The genus Camellia has undergone several taxonomic revisions (Prince, 2007). Sealy (1958) published a revision of the genus Camellia that included 12 sections and 82 species with an additional group of 24 doubtful species. Chang and Bartholomew (1984) and Chang (1998) completed several taxonomic revisions of Camellia and reorganized the 238 species native to China in 18 sections and 4 subgenera. More recently, Ming (2000) published his monograph of the genus Camellia; in that work, he reduced the number of subgenera to 2 , the sections to 14 , and the species to 119 , which was less than half of Chang's final tally of $\approx 280$ species. The systems of both Ming (2000) and Chang (1998) are widely used by botanists today (Gao et al., 2005). In the work by Ming and Bartholomew (2007), the number of species is $\approx 120$, and 97 of these are native to China.

Several changes to the accepted taxonomic status of Camellia have occurred since its original classification by Linnaeus. At different times, Camellia has been placed with the Guttiferales, Theales, and even within Ternstroemiaceae (Luna and Ochoterena, 2004). Theaceae is now considered a distinct family within Ericales (Stevens, 2001 onwards). Luna and Ochoterena (2004) found that Theaceae is closely related to Ternstroemiaceae; both belong to the same clade. Within Theaceae, there are three tribes: Theeae, Gordoniae, and Stewartiae. Theeae is the most diverse of these tribes and contains Camellia, Polyspora, Pyrenaria, Apterosperma, and Laplacea. A recent molecular phylogenetic analysis of Theeae indicated that Camellia and Pyrenaria form a paraphyletic group; these two occur and hybridize naturally with each other (Zhang et al., 2014). Gordoniae and Stewartiae belong to the sister clade of Theeae. Gordoniae 
is composed of the North American Franklinia and Gordonia, as well as the Asian Schima. Intergeneric hybrids between these species as well as between Camellia and Franklinia have been reported (Ackerman and Williams, 1982; Orton, 1977; Ranney et al., 2003; Ranney and Fantz, 2006). Stewartiae includes the disjunct North American and Asian Stewartia (including evergreen species sometimes classified as Hartia) (Prince and Parks, 2001).

\section{Ploidy and Cytogenetics}

There is some variation in the base chromosome number among members of Theaceae. Many genera including Camellia, Polyspora, and Pyrenaria exhibit base chromosome numbers consistently reported as $1 n=1 x=15$ (Kondo, 1977; Yang et al., 2000, 2004). Other genera, however, have inconsistent reports, such as Stewartia with $1 n=1 x=15$ or 17 and Franklinia, Gordonia, and Schima with $1 n=1 x=15$ or 18 (Bostick, 1965; Horiuchi and Oginuma, 2001; Oginuma et al., 1994; Santamour, 1963). For Camellia, there is also considerable variability in ploidy, both among and within species. For example, Camellia japonica is most commonly found to be diploid (Ackerman, 1971; Kondo, 1977), although triploids, tetraploids, pentaploids, and aneuploids have been reported (Fukushima et al., 1966; Kondo, 1977). Although Camellia sasanqua is often reported to be hexaploid (Ackerman, 1971; Kondo, 1977), pentaploids, heptaploids, octoploids, decaploids, and aneuploids have been noted (Ito et al., 1957; Kondo, 1977).

Received for publication 28 Jan. 2019. Accepted for publication 11 Apr. 2019.

This research was funded, in part, by the North Carolina Agricultural Research Service (NCARS), Raleigh, NC. Use of trade names in this publication does not imply endorsement by the NCARS of products named or criticism of similar ones not mentioned. We gratefully acknowledge Clifford and David Parks, Camellia Forest Nursery, Chapel Hill, NC; Gene Phillips, Gene's Nursery, Savannah, GA; Coastal Georgia Botanical Garden, Savannah, GA; Bobby Green, Green Nurseries, Fairhope, AL; Ray Watson, CAM TOO Camellia Nursery, Inc., Greensboro, NC; Scott McMahan, Atlanta Botanical Garden, Atlanta, GA; Gary Knox, University of Florida, North Florida Research and Education Center, Quincy, FL; Kevin Conrad, United States National Arboretum, Washington, D.C.; Donglin Zhang, University of Georgia, Athens, GA; John Ruter, University of Georgia, Athens, GA; Jack Johnston, Lakemont, GA; Star Roses and Plants, West Grove, PA; Gulf Coast Camellia Society, Baton Rouge, LA; Nathan Lynch, Irene Palmer, and Andra Nus, Mountain Crop Improvement Lab, Mills River, NC; and the staff at the Mountain Horticultural Crops Research and Extension Center for their cooperation, technical assistance, plant material, and/or funding for this project.

${ }^{1}$ Graduate Research Assistant.

${ }^{2}$ JC Raulston Distinguished Professor.

${ }^{3}$ Associate Professor.

${ }^{4}$ Director, JC Raulston Arboretum.

${ }^{5}$ Corresponding author. E-mail: tom_ranney@ncsu. edu.
Ploidy series are seen in other Camellia species as well, including (but not limited to) $C$. hiemalis, $C$. oleifera, $C$. reticulata, and $C$. sinensis (Ackerman, 1971; Bezbaruah, 1971; Huang et al., 2013; Kondo, 1977). The variation and confusion regarding ploidy levels are further complicated by and may be partly the result of interspecific and interploid hybridization. For example, advanced hybrids of $C$. $\times$ vernalis $(C$. sasanqua $\times$ japonica) can be triploid, tetraploid, pentaploid, or hexaploid (Tateishi et al., 2007). Additionally, camellias can produce both unreduced gametes (Wendel, 1984) and, in some instances, aneuploid gametes (Kondo, 1977), resulting in additional possible variations within ploidy.

Ploidy and genome size can influence reproductive compatibility, fertility, and heritability of traits. Relative ploidy levels among related taxa can reflect and help elucidate biodiversity, genomic evolution, and taxonomic relationships (Laport and $\mathrm{Ng}, 2017$; Ranney et al., 2018; Soltis et al., 2015). For example, seed development from interploid crosses can be limited by the failure of endosperm formation, leading to the production of nonviable seeds (Ramsey and Schemske, 1998). Anisoploid plants, whose chromosome numbers are in odd multiples of their basic number (e.g., triploid, pentaploid, etc.), can be sterile or have greatly reduced fertility, thereby limiting their potential as breeding lines. With increasing ploidy, allelic segregation becomes more complicated, thus leading to complex patterns of heritability, especially in autopolyploids (Zielinski and Scheid, 2012). Information regarding ploidy and genome size can also be used to confirm interploid hybridity, and genome size data can be used to estimate ploidy among related taxa when calibrated with known cytological standards.

The objectives of this study were to 1 ) conduct an extensive literature review and compile a consolidated reference regarding the cytogenetics of Camellia and related genera, and 2) to augment prior research with original data regarding ploidy and genome sizes of specific accessions of selected species, cultivars, and interspecific and interploid hybrids.

\section{Materials and Methods}

Plant material. Tissue samples of species, hybrids, and cultivars of Camellia and closely related genera were collected from nurseries, private collections, and botanic gardens. Several species not previously reported were surveyed, and putative interploidy and interspecific hybrids were verified or challenged. Taxa with variable reported genome sizes were analyzed to determine the ploidy of specific clones. Cultivars with previously determined chromosome numbers were included to calibrate genome size with ploidy.

Genome size/Ploidy determination. Flow cytometry was used to determine genome sizes following the methods of Huang et al.
(2013). Approximately 40 to $50 \mathrm{mg}$ of leaves were used for each sample preparation. A modified woody plant buffer (WPB) isolation buffer composed of $0.2 \mathrm{~mm}$ Tris- $\mathrm{HCl}, 4 \mathrm{~mm}$ $\mathrm{MgCl}_{2}-6 \quad \mathrm{H}_{2} \mathrm{O}, 2.0 \mathrm{~mm}$ EDTA $\mathrm{Na}_{2}-\mathrm{H}_{2} \mathrm{O}$, $86.0 \mathrm{~mm} \mathrm{NaCl}, 2.0 \mathrm{~mm}$ dithiothreitol, $1 \%$ (w/v) PVP-10, and 1\% (v/v) Triton X-100 1 $\mathrm{mL}$ with a $\mathrm{pH}$ of 7.5 was prepared. Ice-cold nuclei suspensions were prepared by chopping tissue in the WPB with a razor blade. The WPB buffer was used to reduce the effects of phenolic compounds, preserve chromatin integrity in the DNA, and help produce low CV values (Huang et al., 2013). The suspensions were filtered through a $50-\mu \mathrm{m}$ nylon filter. The nuclei were subsequently treated with $50 \mu \mathrm{g} \cdot \mathrm{mL}^{-1}$ RNase and stained with propidium iodide (PI) (Huang et al., 2013). Pisum sativum 'Ctirad' $(2 \mathrm{C}=8.75 \mathrm{pg})$ and Magnolia virginiana 'Jim Wilson' $(2 \mathrm{C}=3.92 \mathrm{pg})$ were used as internal standards. Samples were analyzed using a Partec PA II flow cytometer (Partec, Görlitz, Germany) to determine genome size. Holoploid, somatic, sporophytic, unreduced 2C genome size was calculated as the DNA content of the standard $(\mathrm{pg}) \times($ mean fluorescence value of the sample / mean fluorescence value of the standard). Plants were sampled randomly, with two subsamples measured per plant. Monoploid $1 \mathrm{C} x$ genome size (i.e., the DNA content of one complete set of chromosomes) was calculated as 2C genome size / ploidy.

Chromosome counts were completed for selected taxa to confirm ploidy and further calibrate the flow cytometry results following the methods of Lattier et al. (2014). Root squashes were prepared for selected plants by collecting actively growing root tips and placing them in a prefixative solution of $2.0 \mathrm{~mm} 8$-hydroxyquinoline plus $70 \mathrm{mg} \cdot \mathrm{L}^{-1}$ cyclohexamide in the dark at room temperature for $3 \mathrm{~h}$. The roots were then placed in the dark at $4{ }^{\circ} \mathrm{C}$ for another $3 \mathrm{~h}$. After washing with $\mathrm{dH}_{2} \mathrm{O}$, the roots were transferred to a fixative solution of $1: 3$ propionic acid to $95 \% \mathrm{EtOH}$ at room temperature overnight. The following morning, roots were transferred to a solution of $70 \% \mathrm{EtOH}$ for long-term storage.

To prepare fixed samples for counting, the roots were moved to a hydrolysis solution of $1: 312 \mathrm{M} \mathrm{HCl}$ to $95 \% \mathrm{EtOH}$ for 60 to $90 \mathrm{~s}$ before being moved to a clean slide. Root tips were excised and moved to a final clean slide, and a drop of modified carbol fuschin stain was applied to the root tip (Carr and Walker, 1961; Kao, 1975). A coverslip was placed on the root tip and gently pressed with a pencil eraser to squash the tissue. A light microscope was used to count chromosomes in actively dividing cells and confirm ploidy (Lattier et al., 2014).

Data for monoploid genome sizes (1Cx) were subjected to a one-way analysis of variance (ANOVA) as a function of subfamily, genus, and species; Camellia was subjected to a one-way ANOVA as a function of subfamily, genus, species, subgenus, and section. Means were separated using Fisher's least significant difference test 
Table 1. Previous cytological and cytometric reports of chromosome numbers for Camellia and related taxa.

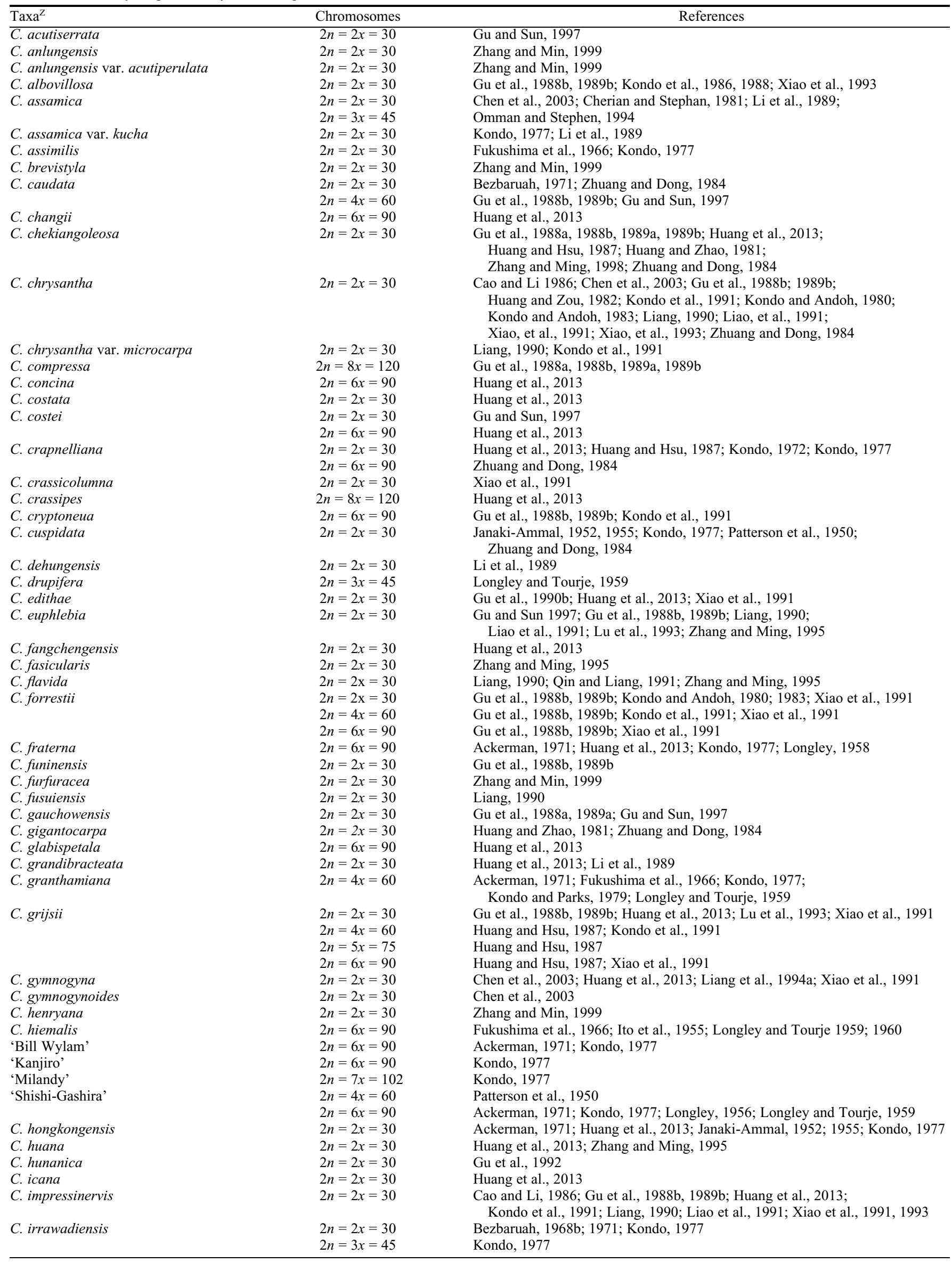


Table 1. (Continued) Previous cytological and cytometric reports of chromosome numbers for Camellia and related taxa.

\begin{tabular}{|c|c|c|}
\hline \multirow{2}{*}{$\frac{\text { Taxa }^{\mathrm{Z}}}{\text { C. japonica }}$} & Chromosomes & References \\
\hline & $2 n=3 x=45$ & $\begin{array}{l}\text { Bezbaruah, 1971; Fukushima et al., 1966; Ito et al., 1955; } \\
\text { Janaki-Ammal, 1952, 1955; Longley, 1958; Longley and Tourje 1960; } \\
\text { Patterson et al., 1950; Uemoto et al., 1980 }\end{array}$ \\
\hline ‘Akashi-Gata’ & $2 n=3 x=45$ & Longley and Tourje, 1960; Ito et al., 1955 \\
\hline ‘Akazu-Nishiki’ & $2 n=2 x=30$ & Ito et al., 1955 \\
\hline 'Akebono' & $2 n=3 x=45$ & Ito et al., 1955 \\
\hline 'Aki-No-Yama' & $2 n=2 x=30$ & Ito et al., 1955 \\
\hline ‘Ara-Jishi' & $2 n=2 x=30$ & Ito et al., 1955 \\
\hline $\begin{array}{l}\text { 'Arrabella' — Open } \\
\text { pollinated seedling }\end{array}$ & $2 n=\approx 2 x=32$ & Kondo, 1977 \\
\hline 'Berenice Boddy' & $2 n=2 x=30$ & Kondo, 1977; Patterson et al., 1950 \\
\hline ‘Bokuhan’ & $2 n=2 x=30$ & Ito et al., 1955 \\
\hline 'Bon-Shirotama' & $2 n=2 x=30$ & Ackerman, 1971 \\
\hline 'California' & $2 n=3 x=45$ & Kondo, 1977 \\
\hline 'Chiri-Tsubaki' & $2 n=2 x=30$ & Ito et al., 1955 \\
\hline ‘Conrad Hilton’ & $2 n=2 x=30$ & Kondo, 1977 \\
\hline 'Coral Pink Lotus' & $2 n=3 x=45$ & Kondo, 1977 \\
\hline 'Daikagura' & $2 n=2 x=30$ & Patterson et al., 1950 \\
\hline 'Donckelarii' & $2 n=2 x=30$ & Kondo, 1977 \\
\hline 'Drama Girl' & $2 n=3 x=45$ & Kondo, 1977 \\
\hline 'Elegans' & $2 n=2 x=30$ & Kondo, 1977 \\
\hline 'Elegans Chandler' & $2 n=2 x=30$ & Kondo, 1977 \\
\hline 'Elena Noble' & $2 n=2 x=30$ & Kondo, 1977 \\
\hline 'Emmet Barnes' & $2 n=3 x=45$ & Kondo, 1977 \\
\hline 'Glenn Allan' & $2 n=2 x=30$ & Kondo, 1977 \\
\hline 'Grandiflora' & $2 n=3 x=45$ & Janaki-Ammal, 1955 \\
\hline 'Hagoromo' & $2 n=3 x=45$ & Kondo, 1977 \\
\hline 'Hakugan’ & $2 n=2 x=30$ & Ito et al., 1955 \\
\hline 'Hana-Guruma' & $2 n=2 x=30$ & Ito et al., 1955 \\
\hline 'Hasumi-Shiro' & $2 n=2 x=30$ & Ackerman, 1971 \\
\hline ‘Hayaoi’ & $2 n=2 x=30$ & Kondo, 1977 \\
\hline 'High Hat' & $2 n=2 x=30$ & Kondo, 1977 \\
\hline 'Higurashi' & $2 n=2 x=30$ & Ito et al., 1955 \\
\hline 'Honpoji-Atsu-Ba' & $2 n=5 x=75$ & Fukushima et al., 1966 \\
\hline 'Iwane' & $2 n=2 x=30$ & Patterson et al., 1950 \\
\hline 'Iwane-Shibori' & $2 n=2 x=30$ & Ito et al., 1955 \\
\hline 'Jenny Jones' & $2 n=2 x=30$ & Patterson et al., 1950 \\
\hline 'Jitsu-Getsu' & $2 n=2 x=30$ & Ito et al., 1955 \\
\hline 'Joshua E. Youtz' & $2 n=2 x=34$ & Kondo, 1977 \\
\hline 'Judge Solomon' & $2 n=2 x=30$ & Kondo, 1977 \\
\hline ‘Kanyo-Tai' & $2 n=2 x=30$ & Ackerman, 1971 \\
\hline 'Kauha-Shiratama' & $2 n=2 x=30$ & Longley and Tourje, 1960 \\
\hline 'Kifukurin-Beni-Karako' & $2 n=2 x=30$ & Ito et al., 1955 \\
\hline 'Kingyo-Ba' & $2 n=2 x=30$ & Ito et al., 1955 \\
\hline 'Kingyo-Tsubaki' & $2 n=2 x=30$ & Longley and Tourje, 1960; Kondo, 1977 \\
\hline ‘Ko-Kirin’ & $2 n=2 x=30$ & Ito et al., 1955 \\
\hline 'Kominato' & $2 n=2 x=30$ & Kondo, 1977 \\
\hline 'Komyo’' & $2 n=3 x=45$ & Ito et al., 1955 \\
\hline ‘Komyo-Tai’' & $2 n=2 x=30$ & Ackerman, 1971 \\
\hline 'Konron-Koku' & $2 n=2 x=30$ & Longley and Tourje, 1960 \\
\hline ‘Ko-Otome’' & $2 n=2 x=30$ & Ito et al., 1955 \\
\hline
\end{tabular}


Table 1. (Continued) Previous cytological and cytometric reports of chromosome numbers for Camellia and related taxa.

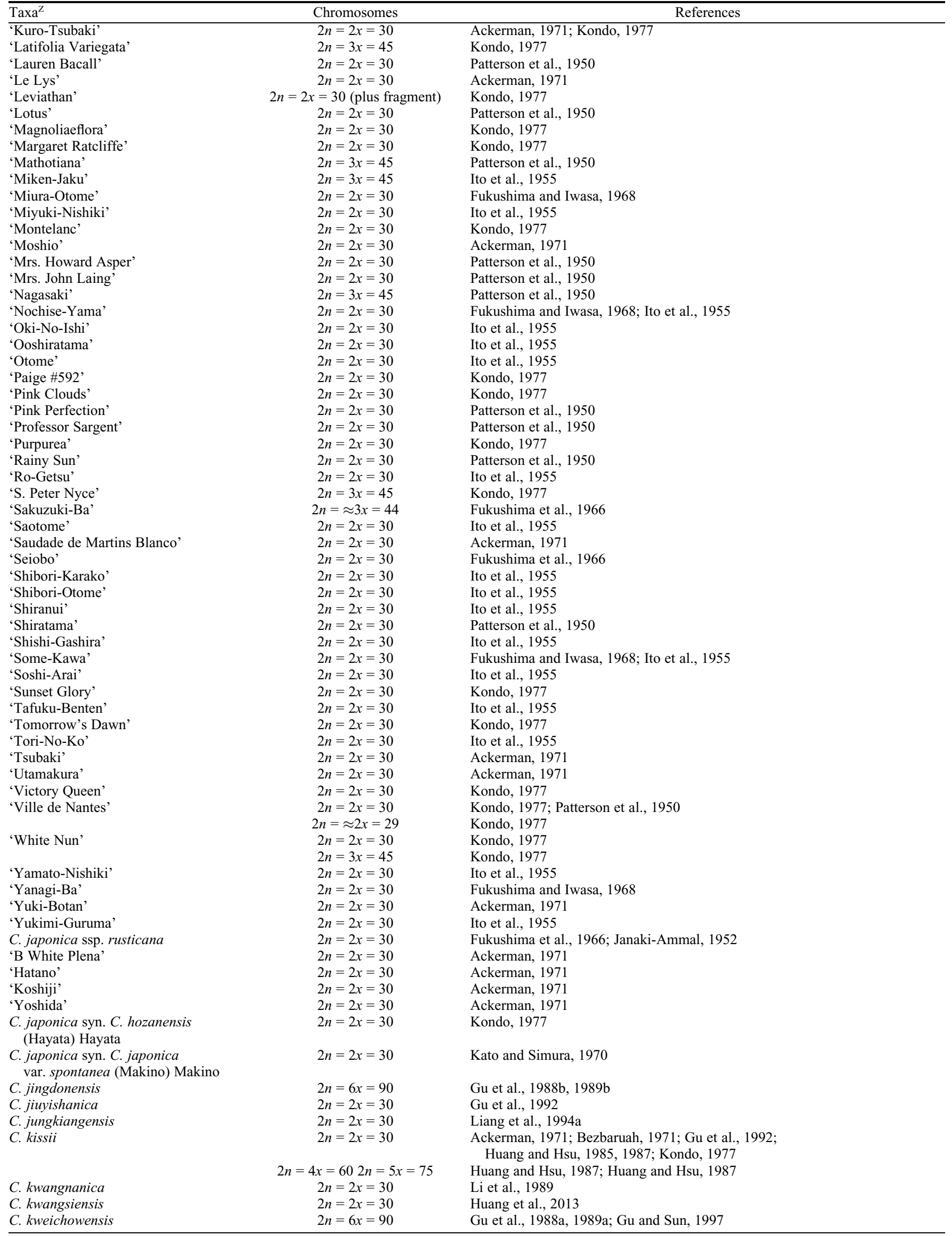


Table 1. (Continued) Previous cytological and cytometric reports of chromosome numbers for Camellia and related taxa.

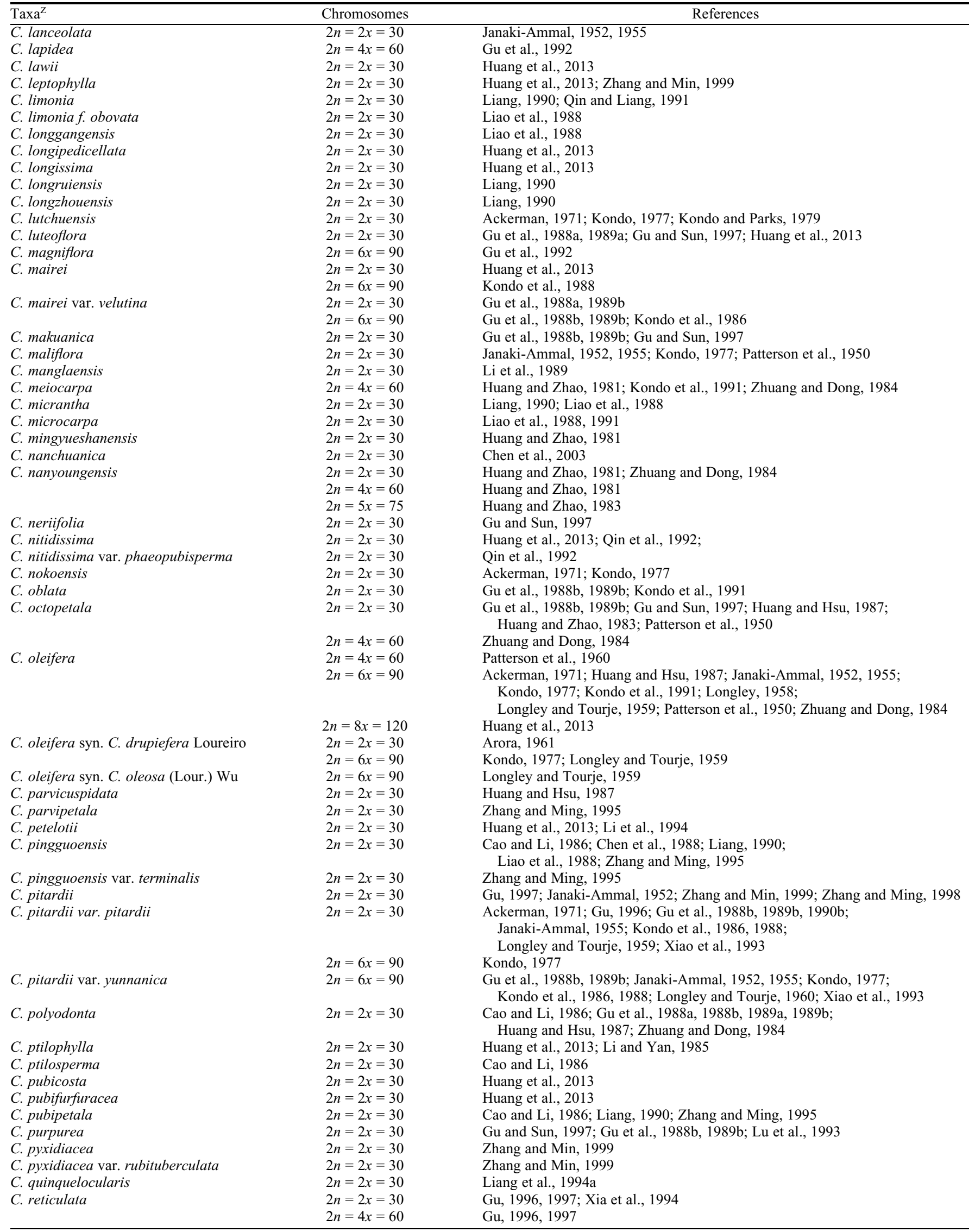


Table 1. (Continued) Previous cytological and cytometric reports of chromosome numbers for Camellia and related taxa.

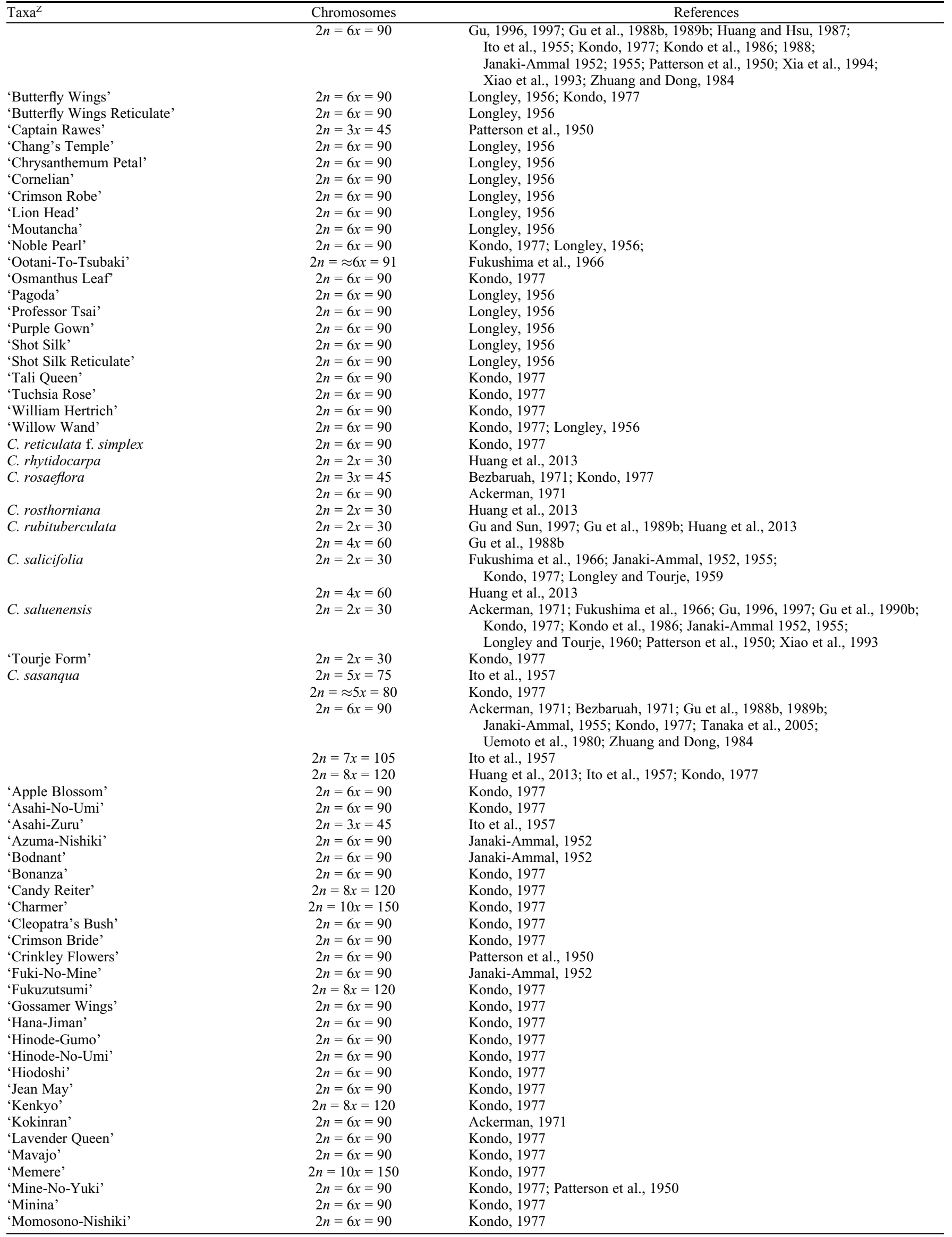


Table 1. (Continued) Previous cytological and cytometric reports of chromosome numbers for Camellia and related taxa.

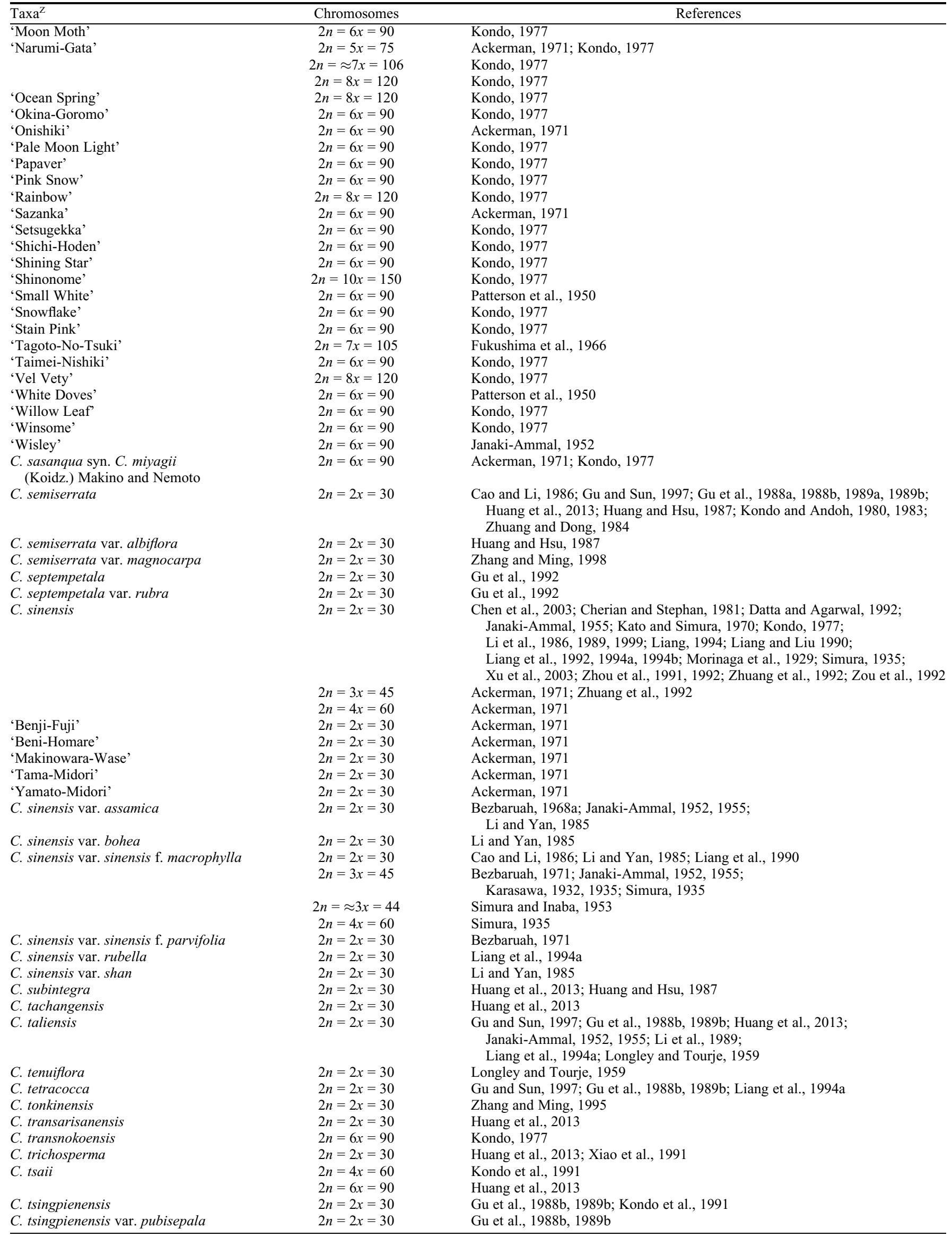


Table 1. (Continued) Previous cytological and cytometric reports of chromosome numbers for Camellia and related taxa.

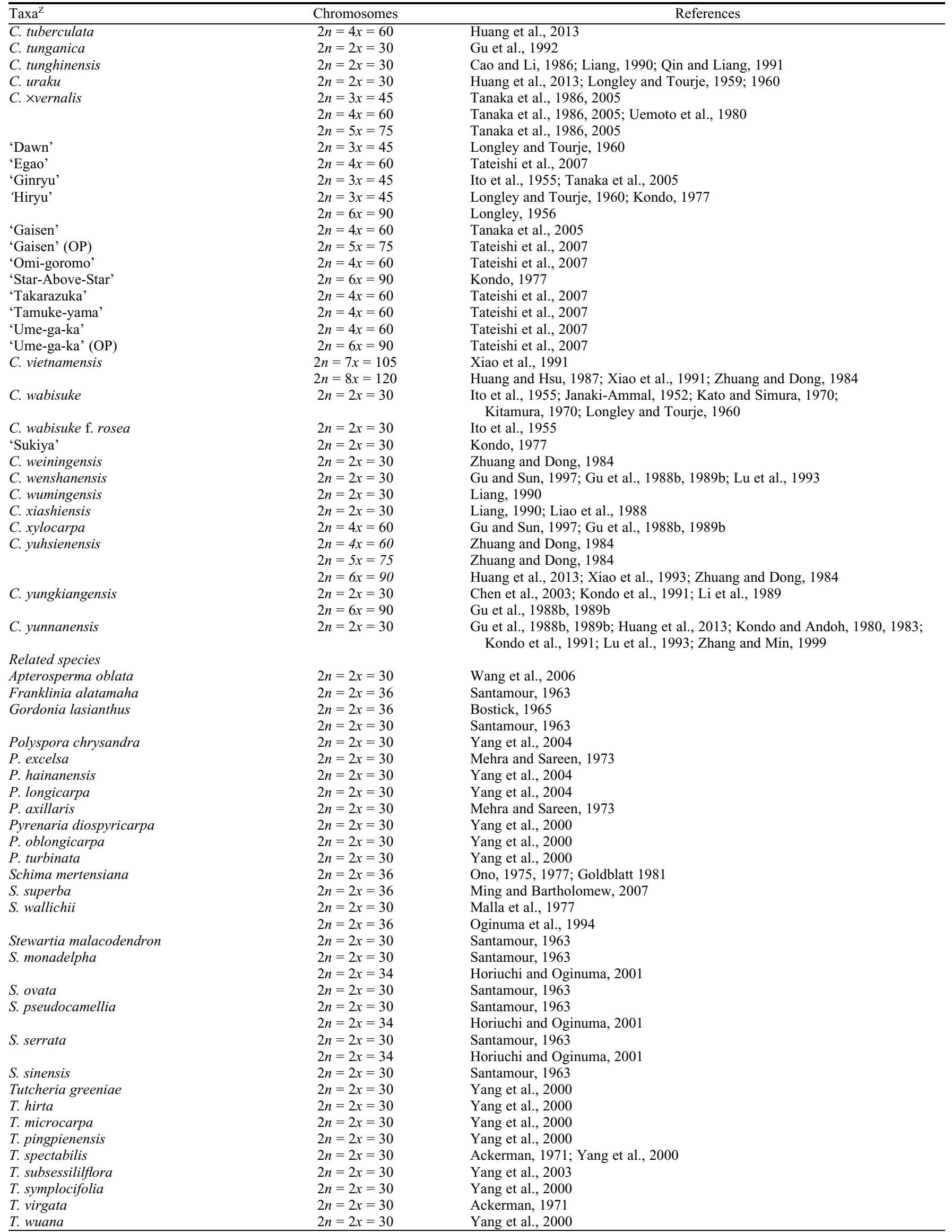

${ }^{\mathrm{z}}$ Nomenclature and species names are listed per the original publications. 

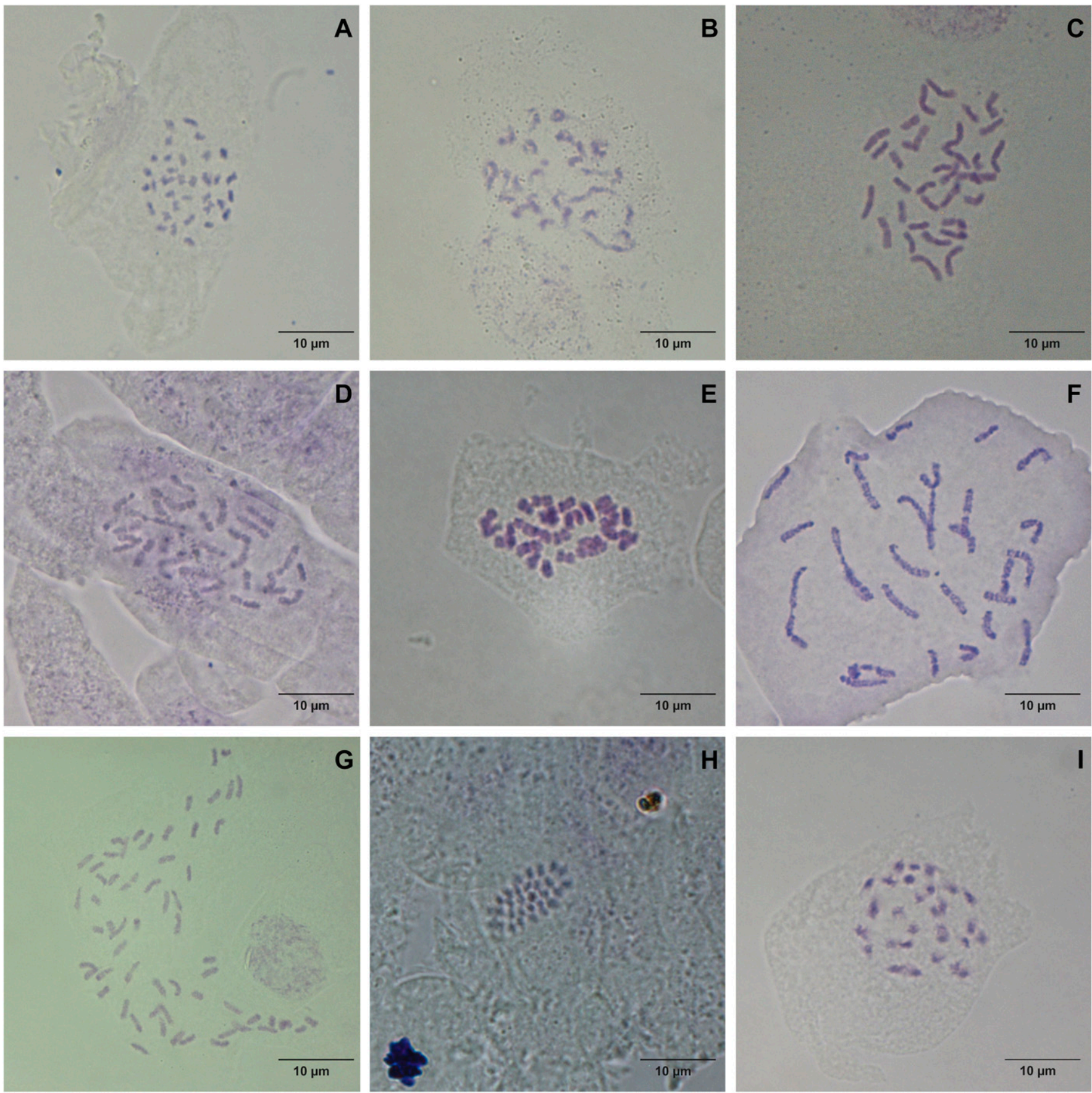

Fig. 1. Photomicrographs of condensed stained chromosomes of Theaceae. (A) Gordonia lasianthus 2006-220, $2 n 2 x=36$. (B) Schima superba 2018-009, $2 n=2 x$ $=36$. (C) Stewartia pseudocamellia 2018-111, $2 n=2 x=34$. (D) Camellia japonica 'Dr. JC Raulston' 2017-060, $2 n=2 x=30$. (E) Camellia sinensis 'Red Leaf' 2017-111, $2 n=2 x=30$. (F) Camellia azalea 2018-063, $2 n=2 x=30$. (G) Camellia $\times$ vernalis 'Egao Corkscrew' 2017-062, 2n=4x=60. (H) Polyspora chrysandra 2015-114, $2 n=2 x=30$. (I) Pyrenaria spectabilis 2018-008 $2 n=2 x=30$.

(Proc GLM; SAS version 9.4; SAS Institute, Cary, NC).

\section{Results and Discussion}

Our compilation of literature regarding the cytogenetics of Theaceae spans nearly one century of research and includes published results for 7 genera, 160 species, and 202 cultivars (Table 1 ). Because cytological studies of Camellia span a broad range of time, many of these referenced studies used different taxonomic treatments dependent on

HortScience Vol. 54(7) July 2019 the naming conventions at the time of publication. Without vouchered specimens, it is essentially impossible to verify exactly which species, according to modern taxonomic treatments, were used during these previous studies. Therefore, the names in Table 1 remain as they were reported in the original publications. As a result, there are numerous taxa represented here by duplicate names, such as $C$. assamica, which is now treated as a variety of $C$. sinensis in the Flora of China (Ming and Bartholomew, 2007). Discrepancies regarding base chromosome numbers continue to be resolved over time, with more recent studies supporting that Theeae, including Apterosperma, Camellia, Polyspora, and Pyrenaria (Tutcheria), has $1 n$ $=1 x=15$ (Kondo et al., 1991; Yang et al., 2000, 2003, 2004). Additional work regarding Stewartiae, including Stewartia, indicated a base chromosome number of $1 n=$ $1 x=17$ (Horiuchi and Oginuma, 2001), whereas Gordoniae, including Franklinia, Gordonia, and Schima, had $1 n=1 x=18$ (Bostick, 1965; Oginuma et al., 1994). Numerous Camellia species have isoploid

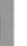


Table 2. Genome sizes and estimated ploidy levels of cultivated Camellia and related taxa.

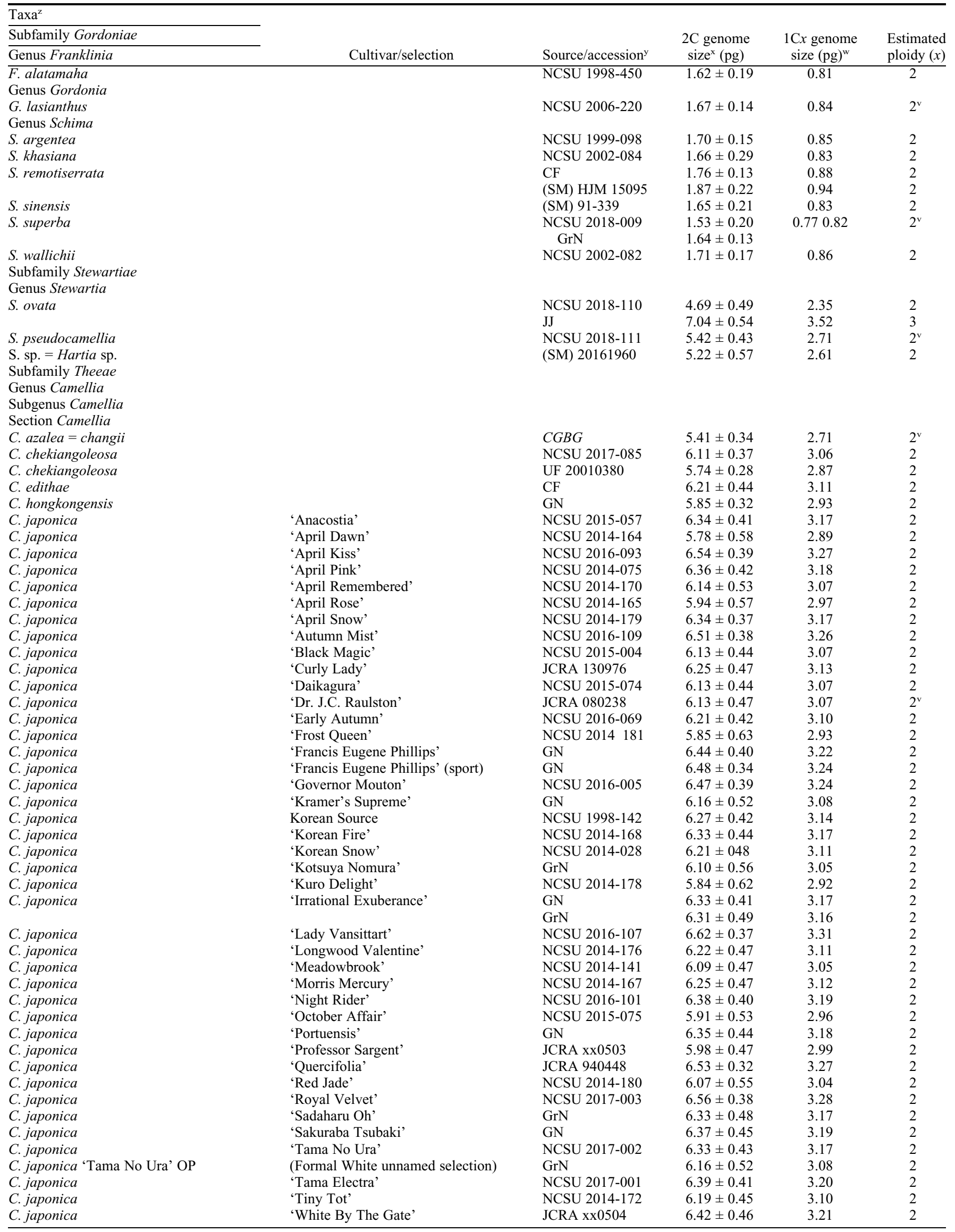

(Continued on next page) 
Table 2. (Continued) Genome sizes and estimated ploidy levels of cultivated Camellia and related taxa.

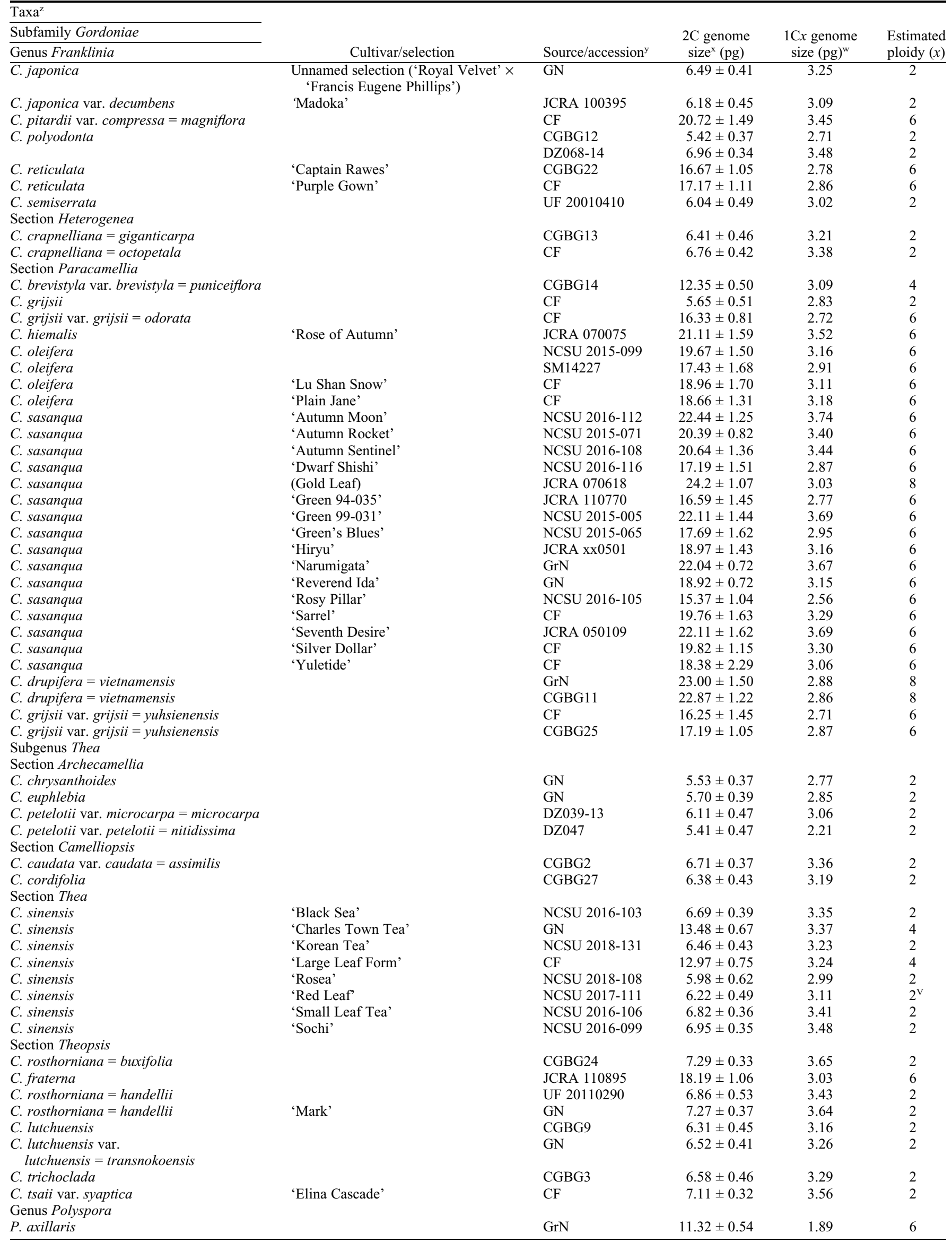


Table 2. (Continued) Genome sizes and estimated ploidy levels of cultivated Camellia and related taxa.

\begin{tabular}{|c|c|c|c|c|c|}
\hline \multicolumn{6}{|l|}{ Taxa $^{2}$} \\
\hline P. axillaris & & UF 20171030 & $3.27 \pm 0.34$ & 1.63 & 2 \\
\hline P. chrysandra & & USNA 81628 & $3.58 \pm 0.32$ & 1.79 & 2 \\
\hline$P$. sp. & & JCRA 131041 & $13.61 \pm 0.75$ & 1.70 & 8 \\
\hline$P$. sp. & & UF 20111400 & $15.69 \pm 0.97$ & 1.96 & 8 \\
\hline P. microcarpa & & $\mathrm{GrN}$ & $3.34 \pm 0.33$ & 1.67 & 2 \\
\hline$P$. spectabilis $=$ Tutcheria spectabilis & & $\mathrm{GrN}$ & $2.66 \pm 0.13$ & 1.33 & $2^{\mathrm{v}}$ \\
\hline $\begin{array}{l}\text { ***Unplaced in Ming \& Barthlomew } \\
\text { (2007) Genus Camellia }\end{array}$ & & & & & \\
\hline C. amplexicaulis & & GN & $4.40 \pm 0.36$ & 2.20 & 2 \\
\hline C. flava & & GN & $5.28 \pm 0.31$ & 2.64 & 2 \\
\hline C. cucphuongensis & & GN & $5.11 \pm 0.40$ & 2.55 & 2 \\
\hline
\end{tabular}

${ }^{\mathrm{z}}$ Taxonomy according to Ming and Bartholomew (2007). Synonyms if applicable, are given.

${ }^{\mathrm{y}} \mathrm{CGBG}=$ Coastal Georgia Botanical Garden, Savannah, GA; CF = Camellia Forest Nursery (Clifford and David Parks), Chapel Hill, NC; DZ = Donglin Zhang, University of Georgia, Athens, GA; GN = Gene's Nursery (Gene Phillips), Savannah, GA; GrN = Green Nurseries, Fairhope, AL; JCRA = JC Raulston Arboretum, Raleigh, NC; NCSU = North Carolina State University Mountain Horticultural Crops Research and Extension Center, Mills River, NC; SM = Scott McMahan, Atlanta Botanical Garden, Atlanta, GA; UF 2 = North Florida Research and Education Center, Quincy, FL; USNA = United States National Arboretum, Washington, DC.

${ }^{\mathrm{x}}$ Holoploid genome sizes were determined using propidium iodide as the fluorochrome stain. Values are $\mathrm{x} \pm \mathrm{SEM}, \mathrm{n}=2-3$.

${ }^{\mathrm{w}} 1 \mathrm{C} x$ values were calculated as $2 \mathrm{C}$ value/ploidy level.

vPloidy levels were confirmed by cytology.

series, including C. caudata, costeri, crapnelliana, forrestii, grijsii, hiemalis, japonica, kissii, mairei, nanyoungensis, octopetala, oleifera, pitardii, reticulata, rubituberculata, salicifolia, saluenensis, sasanqua, sinensis, tsaii, yuhsienensis, and yungkiangensis. There have been occasional reports of anisoploids in C. assamica, irrawadiensis, japonica, rosaeflora, sasanqua, sinensis, vietnamensis, and some cultivars of the interspecific hybrid C. Xvernalis that may have resulted from unreduced gametes, interploid hybridization, or nonrecurrent apomixis (Ozias-Akins and van Dijk, 2007). Previous research summarized in Table 1 has emphasized the cytogenetic diversity within Theaceae and has aided in the understanding of relationships between members of Theaceae. The previous cytogenetic and cytometric data serve as an accessible reference for plant breeders, taxonomists, and others studying Theaceae.

Cytology was completed for representative Theaceae, including species of Camellia, Gordonia, Polyspora, Pyrenaria, Schima, and Stewartia (Fig. 1). Results documented Camellia azalea (2018-063) as $2 n=2 x=30$, Camellia japonica 'Dr. JC Raulston' as $2 n=$ $2 x=30$, Camellia sinensis $(2017-111)$ as $2 n=$ $2 x=30$, Camellia $\times$ vernalis 'Egao Corkscrew' as $2 n=4 x=60$, Gordonia lasianthus (2006-220) as $2 n=2 x=36$, Polyspora chrysandra (2015-114) as $2 n=2 x=30$, Schima superba (2018-009) as $2 n=2 x=$ 36 , Stewartia pseudocamellia (2018-111) as $2 n=2 x=34$, and Pyrenaria spectabilis (2018-008) as $2 n=2 x=30$. These results further substantiate the base chromosome numbers for these genera and provide additional direct standards to further calibrate ploidy with genome size.
Flow cytometry was completed for a broad range of taxa for Theaceae, providing data regarding $2 \mathrm{C}$ holoploid genome size, $1 \mathrm{C} x$ monoploid genome size, and estimated ploidy for 123 nonhybrid accessions (Table 2). Our study represents new data for many cultivars of $C$. japonica, $C$. sasanqua, $C$. sinensis, $C$. oleifera, $C$. rosthorniana, and $C$. hiemalis. Furthermore, the ploidy level of seven previously unreported species of Camellia, including $C$. amplexicaulis, $C$. chrysanthoides, C. cordifolia, C. cucphuongensis, C. flava, C. nanyongensis, and $C$. trichoclada, was found to be diploid. The majority of tested Camellia species exhibited 2C genome sizes consistent with previously reported ploidy, although there were many exceptions (Table 1). The accession of $C$. assimilis CGBG2 was found to be diploid, consistent with the results of Fukushima et al. (1966) and Kondo (1977). Regarding Camellia (Ming and Bartholomew, 2007), C. assimilis is synonymous with $C$. caudata, which has been reported both as diploid (Bezbaruah, 1971; Zhuang and Dong, 1984) and tetraploid (Gu et al., 1988b; 1989b; Gu and Sun, 1997), indicating the existence of a possible ploidy series. Camellia brevistyla, reported by Zhang and Min (1999) as diploid, was found to be tetraploid in this study, although the tested accession was received as C. puniceiflora, which, according to Ming and Bartholomew (2007), is synonymous with $C$. brevistyla var. brevistyla. Camellia grijsii has a reported ploidy series including diploids (Gu et al., 1988b; 1989b; Huang et al., 2013; Lu et al., 1993; Xiao et al., 1991), tetraploids (Huang and Hsu, 1987; Kondo et al., 1991), pentaploids (Huang and Hsu, 1987), and hexaploids (Huang and Hsu, 1987; Xiao et al., 1991). The surveyed accession of $C$. grijsii was diploid, and the accession of $C$. odorata syn. C. grijsii var. grijsii (Ming and Bartholomew, 2007) was hexaploid. Both accessions of $C$. yuhsienensis, which is also synonymous with $C$. grijsii var. grijsii, were hexaploid, although $C$. yuhsienensis has been reported as tetraploid (Zhuang and Dong, 1984), pentaploid (Zhuang and Dong, 1984), and hexaploid (Huang et al., 2013; Xiao et al., 1993; Zhuang and Dong, 1984). Both accessions of C. lutchuensis were diploid, which was in agreement with previous reports (Ackerman, 1971; Kondo, 1977; Kondo and Parks, 1979). However, one of the accessions of $C$. lutchuensis was received as $C$. transnokoensis, which is synonymous with $C$. lutchuensis var. lutchuensis (Ming and Bartholomew, 2007). Kondo (1977) reported $C$. transnokoensis as hexaploid. The surveyed accession of C. reticulata 'Captain Rawes', which was reported to be triploid by Patterson et al. (1950), was found to be hexaploid. Camellia azalea $(=C$. changii), a relatively newly discovered species with considerable breeding potential, was estimated by Huang et al. (2013) to be hexaploid, although the accession of this species surveyed in this study was confirmed to be diploid through flow cytometry and cytology. This result was further supported by the diploidy of $C$. 'Wendzalea', a hybrid of $C$. azalea and $C$. japonica (diploid). The confusion and complexity of Camellia nomenclature and variations in ploidy within species emphasize the need to collect and reference data regarding individual clones and accessions.

The other genera of Theaceae included in this study are muc h less commonly cultivated and have been less studied compared 
Table 3. Monoploid genome sizes $(1 \mathrm{C} x)$, determined by flow cytometry, for Camellia and related taxa grouped by subfamily, section, genus, species within the Theaceae.

\begin{tabular}{|c|c|c|c|c|c|c|c|c|c|}
\hline Subfamily & $1 \mathrm{Cx}(\mathrm{pg})^{\mathrm{z}}$ & Genus & $1 \mathrm{Cx}(\mathrm{pg})^{\mathrm{z}}$ & & & & & Species & $1 \mathrm{Cx}(\mathrm{pg})^{\mathrm{z}}$ \\
\hline$\overline{\text { Gordoniae }}$ & $0.84 \mathrm{C}$ & $\overline{\text { Franklinia }}$ & $0.81 \mathrm{D}$ & Subgenus & $1 \mathrm{Cx}(\mathrm{pg})$ & Section & $1 \mathrm{Cx}(\mathrm{pg})^{\mathrm{z}}$ & F. alatamaha & $0.81 \mathrm{O}$ \\
\hline & & Gordonia & $0.84 \mathrm{D}$ & & & & & G. lasianthus & $0.84 \mathrm{O}$ \\
\hline & & Schima & $0.84 \mathrm{D}$ & & & & & S. argentea & $0.85 \mathrm{O}$ \\
\hline & & & & & & & & S. khasiana & $0.83 \mathrm{O}$ \\
\hline & & & & & & & & S. remotiserrata & $0.91 \mathrm{NO}$ \\
\hline & & & & & & & & S. sinensis & $0.82 \mathrm{O}$ \\
\hline & & & & & & & & S. superba & $0.79 \mathrm{O}$ \\
\hline & & & & & & & & S. wallichii & $0.86 \mathrm{O}$ \\
\hline \multirow[t]{3}{*}{ Stewartiae } & $2.50 \mathrm{~B}$ & Stewartia & $2.50 \mathrm{~B}$ & & & & & S. ovata & $2.34 \mathrm{JK}$ \\
\hline & & & & & & & & S. pseudocamellia & $2.71 \mathrm{HIJ}$ \\
\hline & & & & & & & & S. sp. (Hartia sp.) & $2.61 \mathrm{IJ}$ \\
\hline \multirow[t]{32}{*}{ Theeae } & $3.00 \mathrm{~A}$ & Camellia & $3.13 \mathrm{~A}$ & Camellia & $3.11 \mathrm{~B}$ & Camellia & $3.10 \mathrm{AB}$ & C. azalea & $2.70 \mathrm{HIJ}$ \\
\hline & & & & & & & & C. chekiangoleosa & 2.96 DEFGHI \\
\hline & & & & & & & & C. edithae & 3.11 BCDEFGH \\
\hline & & & & & & & & C. hongkongensis & 2.93 DEFGHI \\
\hline & & & & & & & & C. japonica & 3.13 ABCDEFGH \\
\hline & & & & & & & & C. pitardii & $3.45 \mathrm{ABC}$ \\
\hline & & & & & & & & C. polyodonta & 3.10 BCDEFGH \\
\hline & & & & & & & & C. reticulata & $2.82 \mathrm{GHI}$ \\
\hline & & & & & & & & C. semiserrata & $3.02 \mathrm{CDEFGHI}$ \\
\hline & & & & & & Heterogenea & $3.29 \mathrm{~A}$ & C. crapnelliana & 3.29 ABCDEF \\
\hline & & & & & & Paracamellia & $3.11 \mathrm{AB}$ & C. brevistyla & 3.09 BCDEFGH \\
\hline & & & & & & & & C. drupifera & 2.87 FGHI \\
\hline & & & & & & & & C. grijsii & 2.78 GHIJ \\
\hline & & & & & & & & C. oleifera & 3.11 BCDEFGH \\
\hline & & & & & & & & C. sasanqua & $3.21 \mathrm{ABCDEF}$ \\
\hline & & & & Thea & $3.25 \mathrm{~A}$ & Archecamellia & $2.84 \mathrm{~B}$ & C. chrysanthoides & $2.76 \mathrm{GHIJ}$ \\
\hline & & & & & & & & C. euphlebia & 2.85 FGHI \\
\hline & & & & & & & & C. petelotii & 2.88 EFGHI \\
\hline & & & & & & Eriandria & $3.27 \mathrm{~A}$ & C. caudata & $3.36 \mathrm{ABCD}$ \\
\hline & & & & & & & & C. cordifolia & $3.19 \mathrm{ABCDEFG}$ \\
\hline & & & & & & Thea & $3.32 \mathrm{~A}$ & C. sinensis & $3.32 \mathrm{ABCD}$ \\
\hline & & & & & & Theopsis & $3.38 \mathrm{~A}$ & C. fraterna & $3.03 \mathrm{CDEFGHI}$ \\
\hline & & & & & & & & C. lutchuensis & $3.21 \mathrm{ABCDEF}$ \\
\hline & & & & & & & & C. rosthorniana & $3.57 \mathrm{~A}$ \\
\hline & & & & & & & & C. trichoclada & $3.29 \mathrm{ABCDE}$ \\
\hline & & & & & & & & C. tsaii & $3.56 \mathrm{~A}$ \\
\hline & & Polyspora & $1.75 \mathrm{C}$ & & & & & P. axillaris & $1.69 \mathrm{LM}$ \\
\hline & & & & & & & & P. chrysandra & $1.75 \mathrm{LM}$ \\
\hline & & & & & & & & P. sp. (UF20111400) & $1.96 \mathrm{LK}$ \\
\hline & & & & & & & & P. sp. (JCRA) 131041) & 1.70 LM \\
\hline & & Pyrenaria & $1.39 \mathrm{C}$ & & & & & P. microcarpa & $1.41 \mathrm{M}$ \\
\hline & & & & & & & & P. spectabilis & $1.33 \mathrm{MN}$ \\
\hline
\end{tabular}

Values followed by different letters within a column are significantly different according to Fisher's least significant difference test, $P \leq 0.05$.

with Camellia. Ploidy levels of 24 accessions of six other genera were determined, including Franklinia, Gordonia, Schima, Stewartia, Polyspora, and Pyrenaria. The genus Polyspora (many species of which were previously included in Gordonia) (Yang et al. 2004) was found to have a ploidy series ranging from $2 n=2 x=30$ to $2 n=8 x=$ 120. The ploidy levels of four species of Schima, including $S$. argentea, S. khasiana, $S$. remotiserrata, and $S$. sinensis, have been reported as diploid for the first time. A triploid accession of Stewartia ovata included in this study represented the first polyploid report of this genus; however, this was possibly the result of an unreduced gamete.

Monoploid genome sizes $(1 \mathrm{Cx})$ varied considerably by subfamily (Table 3 ), with the Gordoniae having a mean of $0.84 \mathrm{pg}$, and the Stewartiae and Theeae having substantially larger values of 2.50 and $3.00 \mathrm{pg}$, respectively. The much larger $1 \mathrm{C} x$ values of the Stewartiae and Theeae indicated that they underwent considerable genome expansion independent of increased ploidy levels as these lineages diverged. Genome expansion such as this can occur through amplification of noncoding repetitive DNA including retrotransposons (Leitch and Leitch, 2013). The biological impact of genome size variation is still being elucidated, but the speciation rate has been shown to be correlated with the rate of genomic evolution and genome size (Bromham et al. 2015; Puttick et al., 2015). Within the subfamily Theeae, Camellia also had a significantly higher mean genome size of $3.13 \mathrm{pg}$ compared with $1.75 \mathrm{pg}$ for Polyspora and $1.39 \mathrm{pg}$ for Pyrenaria, indicating differential rates of genome expansion among these groups. Even within Camellia, there were significant differences in $1 \mathrm{Cx}$ values among subgenera, sections, and some species (range, 2.70-3.57 pg), indicating that the evolution of chromosomes and genome size has been particularly dynamic compared with sister lineages.

Genome size has been used to estimate ploidy of interspecific hybrids, and it has been particularly useful for validating inter- ploid and intergeneric hybrids (Table 4). All noninterploid, interspecific Camellia hybrids had estimated ploidy levels that were consistent with their reported parentage. However, the genome size of one putative intergeneric hybrid, $C$. japonica $\times F$. alatamaha (USNA 79387) (Ackerman and Williams, 1982), was inconsistent with the reported parentage. Genome sizes are considerably different for these two parents $(2 \mathrm{C}=5.78-7.11 \mathrm{pg}$ for $C$. japonica and $2 \mathrm{C}=1.62 \mathrm{pg}$ for $F$. alatamaha), yet the putative hybrid was $2 \mathrm{C}=5.94$, effectively discounting hybridity. Many putative interspecific interploid hybrids also had genome sizes and estimated ploidy levels that were inconsistent with their reported parentage. For example, 'Arctic Dawn', 'Fire 'N' Ice', 'Ice Follies', 'Pink Icicle', 'Red Fellow', 'Spring Cardinal', and 'Spring Circus' are all putative hybrids between hexaploid and diploid taxa, yet they have genome sizes consistent with diploids, suggesting they are the result of pollen contamination, mislabeling, or apomixis. Similarly, 'Spring Frill' is a putative hybrid between a 


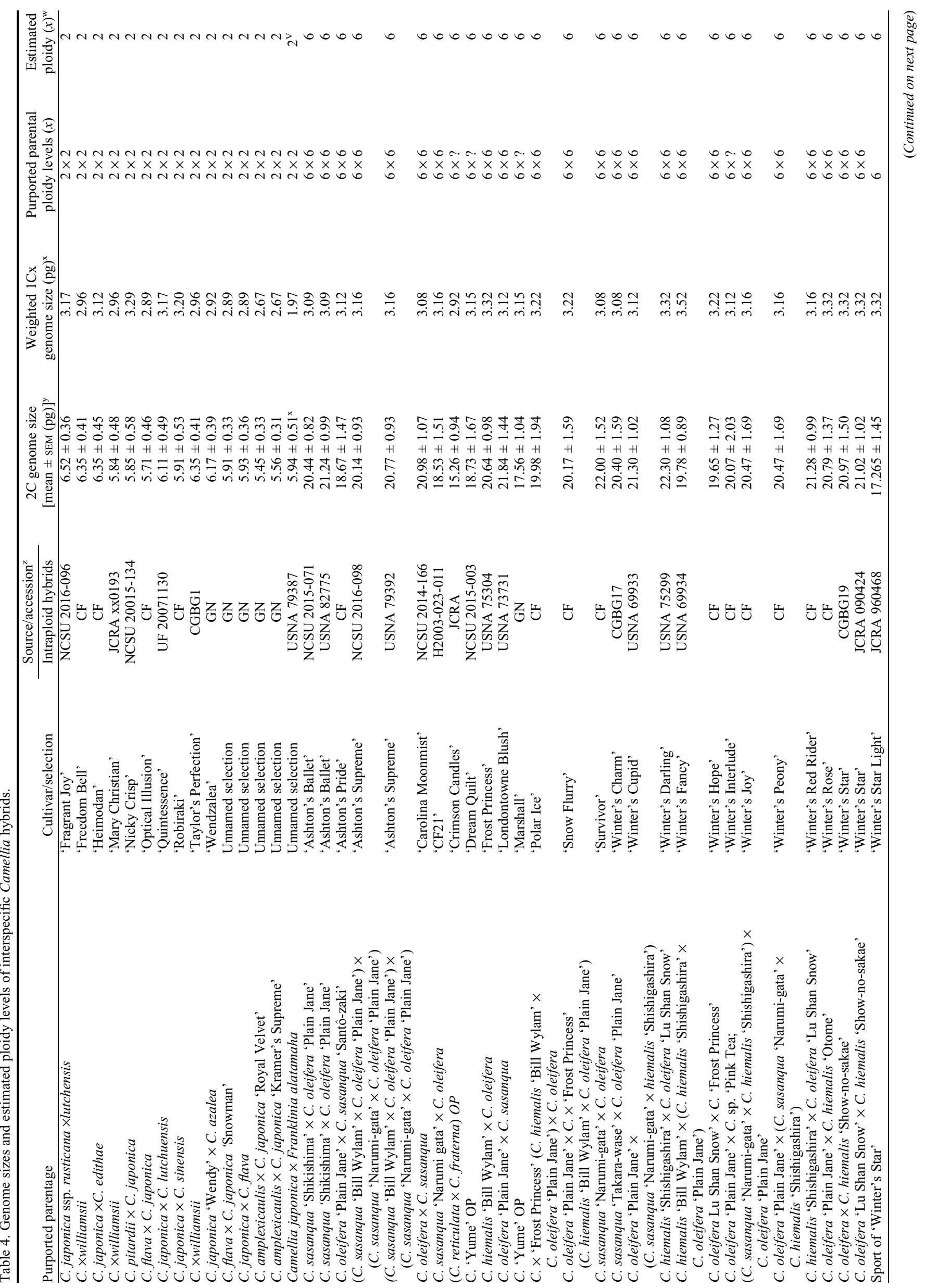




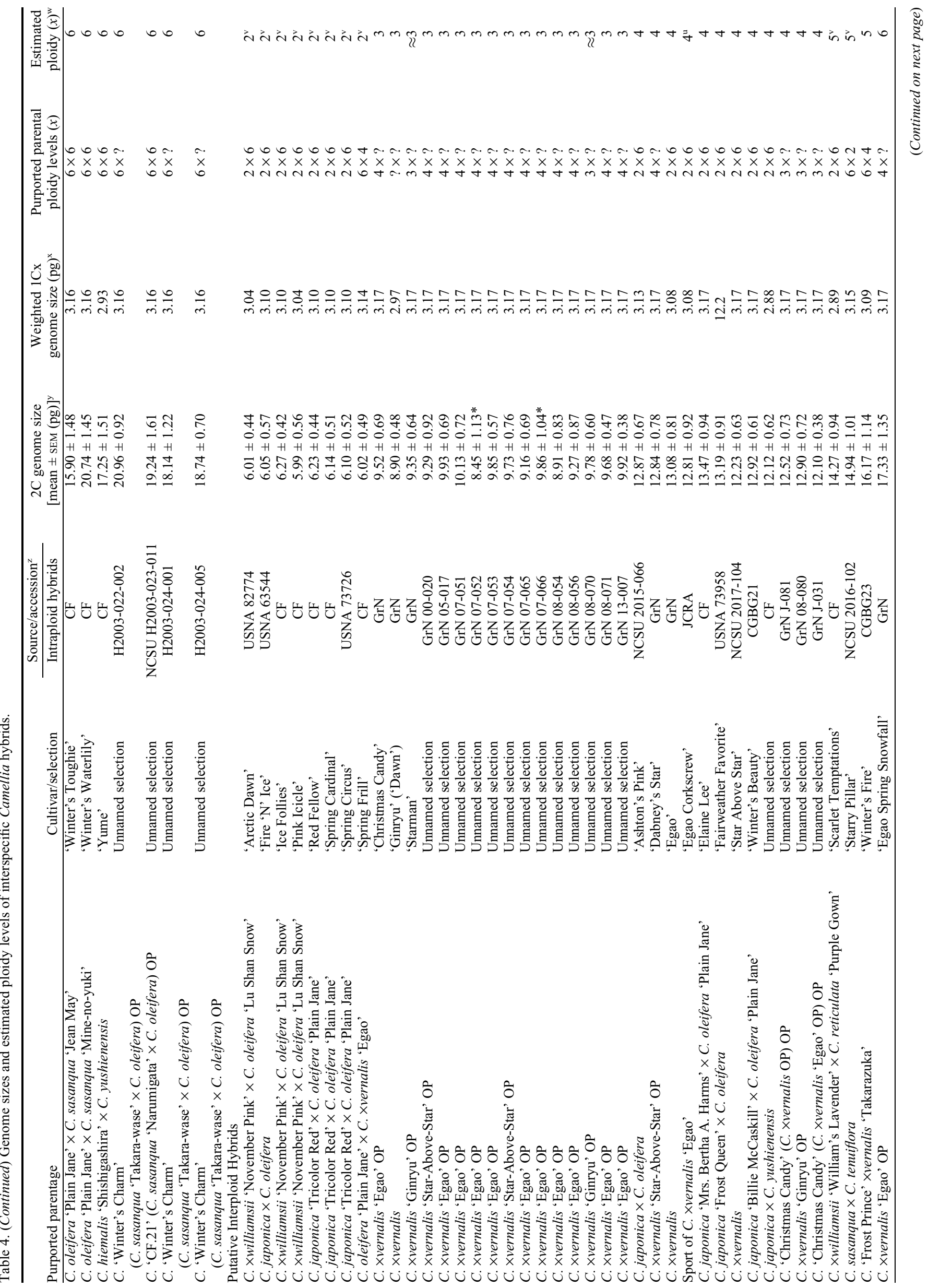

HortScience Vol. 54(7) July 2019 


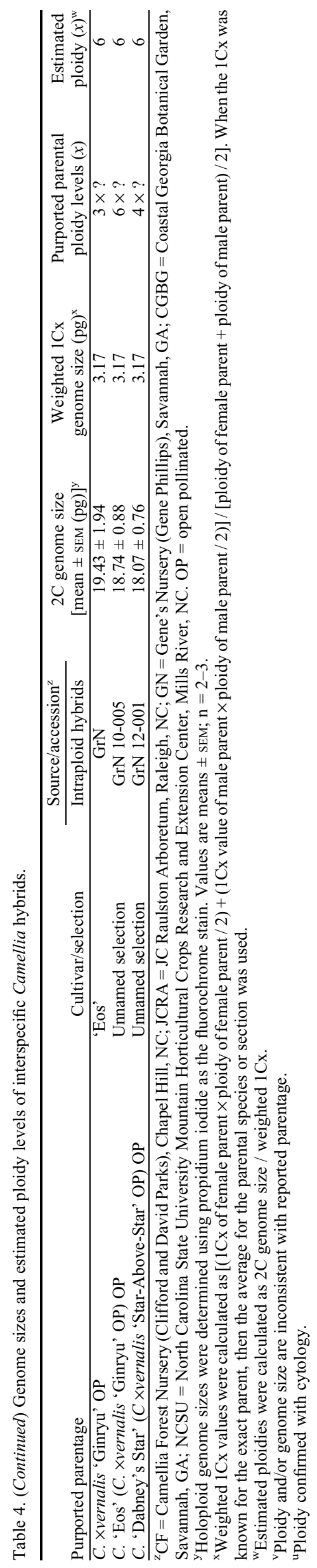

hexaploid and tetraploid, but the estimated ploidy is diploid, suggesting mislabeling. Other interploid hybrids such as 'Scarlet Temptations' and 'Starry Pillar' are crosses between hexaploid and diploid taxa, but they were pentaploid, suggesting they are the result of an unreduced gamete from the diploid parent, as has been documented for Camellia (Wendel, 1984).

Camellia $\times$ vernalis has been documented as a group of interspecific hybrids between $C$. sasanqua and japonica that were originally represented by $\mathrm{F}_{1}$ 'Gaisen'-type tetraploids found on Hirado Island in Japan 400 years ago (Tanaka, 1988a, 1988b; Tanaka et al., 1986, 2005; Uemoto et al., 1980). These hybrids are fertile and can produce progeny that may have three-times, four-times, fivetimes, or six-times the number of chromosomes, or they may be aneuploid, depending on the ploidy of the other parent, occurrence of unreduced gametes, or other meiotic irregularities (Tateishi et al., 2007). Camellia ×vernalis 'Ginryu', also known as its westernized name 'Dawn', was found to be a triploid. This cultivar most likely resulted from a 'Gaisen'-type tetraploid C. ×vernalis backcrossed to a diploid C. japonica. Openpollinated seedlings derived from $C$. xvernalis 'Egao' and 'Star-Above-Star' (both tetraploids) included triploids (most likely crossed with diploids), tetraploids (most likely crossed with other tetraploids), and hexaploids (most likely unreduced gametes from both the tetraploid $C$. $\times$ vernalis and a diploid). Two triploid C. ×vernalis, 'Christmas Candy' and 'Ginryu', produced seedlings that were tetraploid (most likely producing unreduced gametes and crossed with diploids). Interestingly, 'Ginryu' also produced seedlings ('Starman' and GrN 08070) that were triploid or nearly triploid and may have resulted from either apomixis or aneuploid $/ 2 x$ gametes.

The extensive history of Camellia breeding and selection has produced tens of thousands of cultivars that now serve as potential parents and breeding lines. Considerable progress has been made in resolving the taxonomy, systematics, and cytogenetics of the genus, but challenges remain. The long history of Camellia cultivation, global exchange of historical varieties, cultivar names that often relate to the origin of the variety or a quality of the flower, and variable translations can cause considerable confusion. One such name, 'Shishigashira', has been attributed to several species and hybrids, including C. japonica, C. sasan$q u a$, and $C$. hiemalis, which some believe to be a form of C. sasanqua (Jiang et al., 2012). 'Hiryu' is another name that has been associated with $C$. japonica and $C$. sasan$q u a$, as well as with $C$. Xvernalis, which is the hybrid of those two species. This confusion is further complicated by incomplete knowledge of the parentage and ploidy, along with the potential for pollen contamination, mislabeling, and variable reproductive pathways (e.g., unreduced gametes, apomixis, etc.). These challenges underscore the need for clone-specific data regarding cytogenetics for individual accessions and breeding lines.

This study builds on an extensive body of cytogenetic research regarding Camellia and provides new information regarding ploidy, genome size, hybridity, and reproductive pathways for a broad range of cultivated Camellia and related genera. This expanding knowledgebase provides improved characterization of genetic resources for Theaceae that will aid in the development of improved hybrids and cultivars.

\section{Literature Cited}

Ackerman, W.L. 1971. Genetic and cytological studies with Camellia and related genera. Tech. Bul. No. 1427, Agr. Res. Serv., USDA. U.S. Govt. Printing Office, Washington D.C.

Ackerman, W.L. 2007. Beyond the camellia belt. Ball Publ., Batavia, Il.

Ackerman, W.L. and M. Williams. 1982. Intergeneric crosses within Theaceae and the successful hybridization of Camellia japonica and $C$. sasanqua with Franklinia alatamaha. HortScience 17:566-570.

Arora, C.M. 1961. New chromosome report II. Bul. Bot. Surv. India 3:37.

Bartholomew, B. 1986. The Chinese species of Camellia in cultivation. Arnoldia 46:2-15.

Bezbaruah, H.P. 1971. Cytological investigations in the family Theaceae - I. Chromosome numbers in some Camellia species and allied genera. Caryologia 24:421-426.

Bezbaruah, H.P. 1968a. An evaluation of preparatory procedures for leaf-tip chromosome spreads of the tea plant (Camellia sisnesis). Stain Tech. 43:279-282.

Bezbaruah, H.P. 1968b. Cytology of Wilson's camellia (C. irrawadiensis Barua). Curr. Sci. 37:624-625.

Bostick, P.E. 1965. Documented chromosome numbers of plants. 65:2 Sida 2:165-168.

Bromham, L., X. Hua, R. Lanfear, and P.F. Cowman. 2015. Exploring the relationships between mutation rates, life history, genome size, environment, and species richness in flowering plants. Amer. Nat. 185(4):507-524.

Cao, H.J. and T.Q. Li. 1986. The cytological studies of chromosomes of certain Camellia species. J. Beijing For. College 2:35-41.

Carr, D.H. and J.E. Walker. 1961. Carbol fuchsin as a stain for human chromosomes. Stain Technol. 36:233-236.

Chang, H.T. 1998. Genus Camellia, p. 6-194. In: H.T. Chang and S.X. Ren (eds.). Theaceae, Flora Republicae Popularis Sinicae. Sci. Press, Beijing, China.

Chang, H.T. and B. Bartholomew. 1984. Camellias. Timber Press, Portland, OR.

Chen, R.Y., W.Q. Song, X.L. Li, M.X. Li, G.L. Liang, Z.P. An, C.B. Chen, Z.X. Qi, and Y.Z. Sun. 2003. Chromosome atlas of major economic plants genome in China. Tomus II. Chromosome atlas of crops and their wild kindred plants in China relatives. Science Press, Beijing.

Chen, W.S., S.Y. Liang, and L. Cai. 1988. A study on karyotype of Camellia pingguoensis $\mathrm{D}$. Fang. Bull. Bot. Res. Harbin 8:171-175.

Cherian, T.T. and J. Stephan. 1981. Cytology of tea. Cytologia 46:767-772.

Darfler, J.H.L. 2014. Assessing the genetic diversity of ten Camellia taxa. Univ. Delaware, Newark, MS Thesis. 
Datta, M. and B. Agarwal. 1992. Intervarietal differences in karyotype of tea. Cytologia $57: 437-441$.

Fukushima, E., N. Endo, and T. Yoshinari. 1966. Cytogenetic studies in Camellia. I. Chromosome survey in some Camellia species. Jap. J. Hort. 35:413-421.

Fukushima, E. and S. Iwasa. 1968. Cytogenetics in the genus Camellia, p. 33-44. In: T. Tuyama (ed.). Camellias of Japan. Takeda Sci. Found. And Hirokawa Pub. Co., Inc.

Gao, J., C.R. Parks, and Y.Q. Du. 2005. Collected species of the genus Camellia. An illustrated outline. Zheijang Sci. Tech. Press, Zheijang, China.

Goldblatt, P. 1981. Index to Plant Chromosome Numbers 1975-1978. Monogr. Syst. Bot. Missouri Bot. Gard. 6:1-553.

$\mathrm{Gu}$, Z. 1996. A cytological study of Camellia reticulata and its allied species in Jinshajiang Valley, China. Proc. Intl. Symp. Floristic Characteristics and Diversity of East Asian Plants. 82-84. 25-27 July 1996, Kunming, China.

Gu, Z. and X. Sun. 1997. A karyomorphological study of seventeen species of Chinese camellia. Acta Botanica Yunnanica 19(2):159-170.

$\mathrm{Gu}$, Z.J. 1997. The discovery of tetraploid Camellia reticulata and its implication in studies of the origin of this species. Acta Phytotax. Sin. 35:107-116

Gu, Z.J., K. Kondo, H.Y. Na, and L.F. Xia. 1988a. A karyomorphological study in four species of Camellia, section Camellia. Kromosomo 49:1575-1582.

Gu, Z.J., K. Kondo, H.Y. Na, and L.F. Xia. 1989a. A karyomorphological study in four species of Camellia, section Camellia. Amer. Camellia Yrbk. 12-18.

Gu, Z.J., L.F. Xia, L.B. Xie, and K. Kondo. 1989b. Report of the chromosome numbers of some species of Camellia in China. Amer. Camellia Yrbk. 1989:19-22.

Gu, Z.J., L.F. Xia, L.S. Xie, and K. Kondo. 1988b. Report on the chromosome numbers of some species of Camellia in China. Acta Bot. Yunnan. 10:291-296.

Gu, Z., K. Kondo, and Y.S. Kim. 1990a. Variation in karyotype and nucleolus number in Camellia japonica in Daechongdo, Korea. Kromosomo 58:1973-1978.

Gu, Z., K. Kondo, and Y.S. Kim. 1991. Variations in karyotype and nucleolus number in Camellia japonica in Daechongdo, Korea. Camellia J. Yrbk. 1991:109-114.

Gu, Z., T. Xiao, L. Xia, and K. Kondo. 1990b. A comparative study in Giemsa C-banded karyotypes of four species of Camellia, section Camellia. Kromosomo 59:2025-2034.

Gu, Z., T. Xiao, L. Xia, and K. Kondo. 1992. Karyotypes of eight species and one variety of Camellia from Hunan Province, China. Kromosomo 65:2189-2199.

Horiuchi, K. and K. Oginuma. 2001. Karyomorphology of three species of Stewartia (Theaceae) in Japan. Chromosome Sci. 5:79-82.

Huang, H., Y. Tong, Q. Zhang, and L. Gao. 2013. Genome size variation among and within $\mathrm{Ca}$ mellia species by using flow cytometric analysis. PLoS One 8:e64981.

Huang, J. and Q. Zou. 1982. Karyotypical observations on chromosomes of Camellia chrysantha $(\mathrm{Hu})$ Tuyama. Guihaia 2:15-16.

Huang, S.F. and P.S. Hsu. 1985. Karyotype analysis of Camellia kissii Wall. Guihaia 5:369372.

Huang, S.F. and P.S. Hsu. 1987. Chromosome numbers and karyotypes of the oil bearing species of genus Camellia. Subtrop. For. Sci. Technol. 15:33-39.

Huang, S.F. and Z.F. Zhao. 1981. Observation of chromosomes of main species of Chinese Camellia Yalin Keji. Asian For. Sci. Technol. 4:18-24.

Huang, S.F. and Z.F. Zhao. 1983. Analysis of karyotype of Camellia octopetala Hu Yalin Keji. Asian For. Sci. Technol. 2:31-33.

International Camellia Society (ICS). 2015. The international camellia register. 11 Oct. 2018. $<$ https://internationalcamellia.org/internationalcamellia-register>.

Ito, H., E. Fukushima, and K. Arisumi. 1955. On the differentiation of the garden varieties in the genus Camellia. I. On the camellias (a preliminary note). Japn. J. Breed. 5 (Suppl.): 24.

Ito, H., E. Fukushima, and K. Arisumi. 1957. On the differentiation of the garden varieties in the genus Camellia. II. C. sasanqua and its allied species. Annu. Mtg. Jpn. Soc. Hort. Sci. 18-19 (abstr.).

Janaki-Ammal, E.K. 1952. Chromosome relationships in cultivated species of Camellia. Amer. Camellia Yrbk. 1952:106-114.

Janaki-Ammal, E.K. 1955. Theaceae (Ternstroemiaceae), p. 109. In: C.D. Darlington and A.P. Wylie (eds.). Chromosome atlas of flowering plants. Allen and Unwin, London.

Jiang, W., M. Nitin, B. Jiang, Y.P. Zheng, S.S. Hong, and H.F. Lu. 2012. Floral morphology resolves the taxonomy of Camellia L. (Theaceae) sect. Oleifera and sect. Paracamellia. Bangladesh J. Plant Taxon. 19(2):155-165.

Karasawa, K. 1932. On triploid Thea. Bot. Mag. Tokyo 46:458-460.

Karasawa, K. 1935. On the somatic chromosome number of triploid Thea. Jap. J. Genet. 11:320.

Kao, K.N. 1975. A nuclear staining method for protoplasts, p. 60-64. In: O.L. Gamborg and L.Z. Wetter (eds.). Plant tissue culture methods. L.R. National Research Council of Canada, Prairie Regional Laboratory, Saskatoon, Saskatchewan, Canada.

Kato, M. and T. Simura. 1970. Cytogenetical studies on Camellia species. I. The meiosis and gametogenesis of Camellia wabisuke compared with $C$. japonica and $C$. sinensis. Japanese J. Breeding. 20:200-210.

Kitamura, S. 1970. Uraku tsubaki no shozoku. Acta Phytotax. Geobot. 24:173-174.

Kondo, K. 1972. The chromosome number of Camellia crapnelliana. J. Japanese Bot. 47:214.

Kondo, K. 1977. Chromosome numbers in the genus Camellia. Biotropica 9:86-94.

Kondo, K. and C.R. Parks. 1979. Giemsa C-banding and karyotype of Camellia (C-banded karyotypes can tell more detail on inter- and intraspecific relationships in Camellia). Amer. Camellia Yrbk. 1979:40-47.

Kondo, K. and Y. Andoh. 1980. Karyomorphological studies in some species of Camellia L. Phyton. 39:49-56.

Kondo, K. and Y. Andoh. 1983. Karyomorphological studies in some species of Camellia $\mathrm{L}$. Amer. Camellia Yrbk. 1983:45-51.

Kondo, K., K. Taniguchi, N. Tanaka, L. Xia, and Z. Gu. 1991. A karyomorphological study of twelve species of Chinese Camellia. Kromosomo 62:2107-2114.

Kondo, K., Z. Gu, H. Na, and L. Xia. 1986. A cytological study of Camellia reticulata and its closely related species in Yunnan, China. Kromosomo 43-44:1405-1419.

Kondo, K., Z. Gu, H. Na, and L. Xia. 1988. A cytological study of Camellia reticulata and its closely related species in Yunnan, China. Amer. Camellia Yrbk. 1988:72-87.
Laport, R.G. and J. Ng. 2017. Out of one, many: The biodiversity considerations of polyploidy. Amer. J. Bot. 104(8):1119-1121.

Lattier, J.D., T.G. Ranney, P.R. Fantz, and T. Avent. 2014. Identification, nomenclature, genome sizes, and ploidy levels of Liriope and Ophiopogon taxa. HortScience 49:145-151.

Leitch, I.J. and A.R. Leitch. 2013. Genome size diversity and evolution in land plants, p. $307-$ 322. In: I.J. Leitch, J. Greilhuber, J. Dolezel, and J. Wendel (eds.). Plant genome diversity, Vol. 2. Springer-Verlag, Wien, Germany.

Li, B., G.B. Chen, L.X. He, W.Y. Zhang, and G.A. Huang. 1999. Study on chromosome numbers of 10 tea varieties in Guangxi and Guangdong. Guihaia 19:233-235.

Li, B., X.Y. Chen, G.B. Chen, and J.G. Wang. 1986. The analysis of karyotype in tea plant. J. Tea Sci. 6:7-14.

Li, G.T., R. Wu, and T. Liang. 1989. Studies on chromosome number of some Camellia species in China. J. Yunnan Agric. Univ. 4:256-263.

Li, M.X. and X.C. Yan. 1985. Studies on karyotypes of some wild and cultivated tea in China. J. Wuhan Bot. Res. 3:319-324.

Li, M.X., R.L. You, W.L. Bai, and J.S. Chen. 1994. Somatic meiosis of anther callus culture in Camellia petelotii. Acta Bot. Yunnan. 16: 263-267.

Liang, G.L. 1994. Configurational transformation in chromosome G-bands and microcoils of Camellia sinensis. J. Southwest Agr. Univ. 16:116-119.

Liang, G.L., C.Q. Zhou, M.J. Lin, J.Y. Chen, and J.S. Liu. 1994a. Karyotype variation and evolution of sect. Thea in Guizhou. Acta Phytotax. Sin. 32:308-315.

Liang, G.L., M.J. Lin, J.Y. Chen, and J.S. Liu. 1992. Cytotaxonomical studies of tea plants. Acta Phytotax. Sin. 30:498-507.

Liang, G.L., S.S. Wang, X.L. Li, and C.Q. Zhou. 1994b. Studies on the chromosome macrocoiling structure at mitosis in Camellia sinensis. J. Southwest. Agr. Univ. 16:111-115.

Liang, G.L., X.L. Li, and H.S. Kang. 1990. A study on high-resolution G-banding pattern in tea. Acta Genet. Sin. 17:94-97.

Liang, S.Y. 1990. A preliminary study of Camellia chrysantha of Guangxi, China. Guangxi Forest Sci. Technol. 1:1-66.

Liang, Y.R. and Z.S. Liu. 1990. A primary study on the significance of karyotypes in tea taxonomy. Acta Agr. Univ. Zhejiang. 16:88-93.

Liao, H.R., T.L. Lu, and F.F. Li. 1988. Chromosome observations on pollen mother cells of six species of yellow-flowered Camellia. J. Guangxi Agr. College 7:39-42.

Liao, H.R., T.L. Lu, and F.F. Li. 1991. Comparison of karyotypes of four species of Camellia sect. Chrysantha. Guihaia 11:157-161.

Longley, A.E. 1956. In: E.C. Tourje (ed.). 1958. Camellia culture. Southern California Camellia Society, Macmillan, NY.

Longley, A.E. and E.C. Tourje. 1959. Chromosome numbers of certain Camellia species and allied genera. Amer. Camellia Yrbk. 1959: 33-39.

Longley, A.E. and E.C. Tourje. 1960. Chromosome numbers of certain Camellia species and allied genera. Amer. Camellia Yrbk. 1960:70-72.

Lu, H.F., L.H. Zhou, Z.J. Gu, and L.F. Xia. 1993. Studies on the karyotypes of five species of Camellia. J. Yunnan Agr. Univ. 8:307-311.

Luna Vega, I. and R. Contreras-Medina. 2000. Distribution of the genera of Theaceae (Angiospermae: Theales) A panbiogeographic analysis. Biogeographica 76(2):79-88. 
Luna, I. and H. Ochoterena. 2004. Phylogenetic relationships of the genera of Theaceae based on morphology. Cladistics 20:223-270.

Malla, S.B., S. Bhattarai, M. Gorkhali, and H. Saiju. 1977. IOPB chromosome number reports LVII. Taxon 26:444-446.

Mehra, P.N. and T.S. Sareen. 1973. Cytology of some Himalayan trees. Silvae Genet. 22:66-70.

Ming, T. 2000. Monograph of the genus Camellia. Yunnan Sci. and Technol. Press, Kunming, China.

Ming, T. and B. Bartholomew. 2007. Camellia, p. 367-412. In: Z.Y. Wu, P.H. Raven, and D.Y. Hong (eds.). Flora of China.

Morinaga, T., T. Kano, Y. Maryuama, and Y. Yamasaki. 1929. Chromosome numbers of cultivated plants II. Bot. Mag. Tokyo 43:589-594.

Morinaga, T. and E. Fukushima. 1931. Chromosome numbers of cultivated plants III. Bot. Mag. Tokyo 45:140-145.

Oginuma, K., H. Tobe, and H. Ohba. 1994. Chromosomes of some woody plants from Nepal. Acta Phytotaxon. Geobot. 45(1):15-22.

Omman, P. and J. Stephen. 1994. Cytology of a triploid tea. J. Cytol. Genet. 29(1):1-7.

Orton, E.R., Jr. 1977. Successful hybridization of Gordonia lasianthus (L.) Ellis $\times$ Franklinia alatamaha Marshall. Amer. Assoc. Bot. Garden Arb. Bul. 11:81-84.

Ozias-Akins, P. and P.J. van Dijk. 2007. Mendelian genetics of apomixis in plants. Annu. Rev. Genet. 41:509-537.

Patterson, E.B., M.O. Longley, and D.S. Robertson. 1950. Chromosome numbers in cultivated camellias. Amer. Camellia Yrbk. 1950:107113.

Prince, L.M. 2007. A brief nomenclatural review of genera and tribes in Theaceae. Aliso 24: 105-121.

Prince, L.M. and C.R. Parks. 2001. Estimation of phylogenetic relationships of Theoideae (Theaceae) inferred from chloroplast DNA sequence data. Amer. J. Bot. 88:2309-2320.

Puttick, M.N., J. Clark, and P.C.J. Donoghue. 2015. Size is not everything: Rates of genome size evolution, not $C$-value, correlate with speciation in angiosperms. Proc. Biol. Sci. 282(1820): 20152289.

Qin, X.M. and Q.H. Liang. 1991. A comparative study on karyotypes in three species of the genus Camellia and their regenerated plants in tissue culture. Acta Bot. Yunnan. 13:51-57.

Qin, X.M., C.W. Gao, Q.H. Liang, and S.Y. Liang. 1992. Karyotype comparison between Camellia nitidissima var. phaeopubisperma and $C$. nitidissima. Guangxi For. Sci. Technol. 21:2-4.

Ramsey, J. and D.W. Schemske. 1998. Pathways, mechanisms, and rates of polyploid formation in flowering plants. Annu. Rev. Ecol. Syst. 29:467-501.

Ranney, T.G. and P.R. Fantz. 2006. xGordlinia grandiflora (Theaceae): An intergeneric hybrid between Franklinia alatamaha and Gordonia lasianthus. HortScience 41:1386-1388.

Ranney, T.G., T.A. Eaker, P.R. Fantz, and C.R. Parks. 2003. xSchimlinia floribunda (Theaceae): A new intergeneric hybrid between Franklinia alatamaha and Schima argentea. HortScience 38:1198-1200.
Ranney, T.G., C.F. Ryan, L.E. Deans, and N.P. Lynch. 2018. Cytogenetics and genome size evolution in Illicium L. HortScience. 53:620 623.

Santamour, F., Jr. 1963. Cytological studies in the Theaceae. Morris Arboretum Bulletin 14:5153.

Sealy, J.R. 1958. A revision of the genus Camellia. Royal Hort. Soc., London.

Simura, T. 1935. Cytological investigations in tea plant (A preliminary report). Proc. Crop Sci. Soc. Japan 7:121-133.

Simura, T. and T. Inaba. 1953. Studies on the polyploid in the tea plant. Japn. J. Breed. 2: 205-213.

Soltis, P.S., D.B. Marchant, Y. Van de Peer, and D.E. Soltis. 2015. Polyploidy and genome evolution in plants. Curr. Opin. Genet. Dev. 35:119-125.

Stevens, P.F. 2001 onwards. Angiosperm Phylogeny Website. Version 14, July 2017 [and more or less continuously updated since]. <http:// www.mobot.org/MOBOT/research/APweb/>.

Tanaka, R. 1974. Organizational system of meiotic division and the development of reproductive cells in higher plants. Cell 6:22-25.

Tanaka, T. 1988a. Cytogenetic studies on the origin of Camellia $\times$ vernalis. 3. A method to identify the cultivars using self-incompatibility. J. Jpn. Soc. Hortic. Sci. 56(4):452-456.

Tanaka, T. 1988b. Cytogenetic studies on the origin of Camellia $\times$ vernalis. 4 . Introgressive hybridization of $C$. sasanqua and $C$. japonica. J. Jpn. Soc. Hortic. Sci. 57(3):499-506.

Tanaka, T., N. Hakoda, and S. Uemoto. 1986. Cytogenetic studies on the origin of Camellia vernalis. 2. Grouping of Camellia vernalis cultivars by the chromosome numbers and the relationships between them. J. Jpn. Soc. Hort. Sci. 55(2):207-214.

Tanaka, T., T. Mizutani, M. Shibata, N. Tanikawa, and C.R. Parks. 2005. Cytogenetic studies on the origin of Camellia $\times$ vernalis. 5. Estimation of the seed parent of $C$. ×vernalis that evolved about 400 years ago by cpDNA analysis. J. Jpn. Soc. Hort. Sci. 74:464-468.

Tateishi, N., Y. Ozaki, and H. Okubo. 2007. Occurrence of ploidy variation in Camellia $\times$ vernalis. J. Fac. Agr. Kyushu Univ. 52:11-15.

Terasaka, O. and R. Tanaka. 1974. Cytological studies on the nuclear differentiation in microspore division of some angiosperms. Bot. Mag. Tokyo 87:209-217.

Trehane, J. 2007. Camellias. Timber Press, Portland, Oregon.

Uemoto, S., T. Tanaka, and K. Fujieda. 1980 Cytogenetic studies on the origin of Camellia vernalis. 1 . On the meiotic chromosomes in some related Camellia forms in Hirado Island. J. Jpn. Soc. Hort. Sci. 48:475-482.

Wang, Y.H., H. He, T.L. Min, L.H. Zhou, and P.W Fritsch. 2006. The phylogenetic position of Apterosperma (Theaceae) based on morphological and karyotype characters. Plant Syst. Evol. 260:39-52.

Wendel, J. 1984. Electrophoretic identification of polyploid Camellia japonica (Theaceae) cultivars and evidence for sexual origin. Plant Syst. Evol. 143:223-226.
Xia, L., Z.J. Gu, Z.L. Wang, T.J. Xiao, L. Wang, and K. Kondo. 1994. Dawn on the origin of Camellia reticulata - the new discovery of its wild diploid in Jinshajiang valley. Amer. Camellia Yrbk. 1994:53-59.

Xiao, T.J., Z.J. Gu, and L.F. Xia. 1993. A study on meiosis of 9 species in genus Camellia. Acta Bot. Yunnan. 15:167-172.

Xiao, T., L. Xia, and K. Kondo. 1991. A karyomorphological study of ten species of Chinese Camellia. Camellia J. Yrbk. 1991:130-137.

Xin, T., J. Riek, H. Guo, D. Jarvis, L. Ma, and C. Long. 2015. Impact of traditional culture on Camellia reticulata in Yunnan, China. J. Ethnobiology Ethnomedicine 11:74.

Xu, L.L., L. Fang, L. Liao, and Q.S. Fan. 2003. Study on karyotypes and isozyme of esterase in the natural mutant strain-Dayelongcha. Guihaia 23:558-560.

Yang, S.X., X. Gong, H. Peng, and Z.Y. Wu. 2000. A cytotaxonomic study on the genus Pyrenaria complex (Theaceae). Caryologia 53:245-253.

Yang, S.X., H. Peng, and Z.Y. Wu. 2003. Taxonomic treatment and karyomorphology of Tutcheria subsessiliflora (Theaceae). Guihaia 23(1):23-26.

Yang, S.X., J.B. Yang, L.G. Lei, D.Z. Li, H. Yoshino, and T. Ikeda. 2004. Reassessing the relationships between Gordonia and Polyspora (Theaceae) based on the combined analyses of molecular data from the nuclear, plastid, and mitochondrial genomes. Plant Syst. Evol. 248:45-55.

Zhang, W., S. Kan, H. Zhao, Z. Li, and X. Wang. 2014. Molecular phylogeny of tribe Theeae (Theaceae s.s.) and its implications for generic delimitation. PLoS One 9:e98133.

Zhang, W.J. and T.L. Min. 1999. A report on karyotypes of nine species and two varieties of the genus Camellia. Acta Bot. Yunnan 21:51-56.

Zhang, W.J. and T.L. Ming. 1995. Karyotypical study of sect. Archecamellia of genus Camellia. Acta Bot. Yunnan. 17:48-54.

Zhang, W.J. and T.L. Ming. 1998. A cytogeographical study of Camellia, sect. Camellia. Acta Bot. Yunnan 20:321-328.

Zhou, J., K. Kondo, and M. Kato. 1991. Karyotypes in wild type and some cultivars of Camellia sinensis var. sinensis (Theaceae). Kromosomo 63-64:2159-2167.

Zhou, J., K. Kondo, and M. Kato. 1992. Karyotypes of six strains of Camellia sinensis. Kromosomo 66:2269-2274.

Zhuang, R.1. and R.X. Dong. 1984. Preliminary observation on pollen size, variation, and chromosome number of major species of Camellia oleosa. For. Sci. Technol. 3:15-17.

Zhuang, W.J., X.P. Wang, and Z.1. Lin. 1992. Karyotypes of tea cultivars. Bot. J. South China $1: 28-34$.

Zielinski, M.L. and O.M. Scheid. 2012. Meiosis in polyploid plants, p. 33-55. In: P.S. Soltis and D.E. Soltis (eds.). Polyploidy and genome evolution. Springer-Verlag, Berlin.

Zou, Q.1., X.J. Qin, and S.1. Qin. 1992. Karyotype studies on six varieties of Camellia in Guangxi. Guihaia 12(4):340-344. 